\title{
REVIEW
}

\section{Environmental change in the eastern tropical Pacific Ocean: review of ENSO and decadal variability}

\author{
Paul C. Fiedler* \\ National Marine Fisheries Service, Southwest Fisheries Science Center, PO Box 271, La Jolla, California 92038, USA
}

\begin{abstract}
Interannual variability of the physical environment in the eastern tropical Pacific Ocean (ETP) and biological effects of this variability are reviewed and compared to variability in the northeastern Pacific. El Niño Southern Oscillation (ENSO) scale variability of 2 to 7 yr periods is dominant in the eastern equatorial Pacific and decadal scale variability of 10 to $30 \mathrm{yr}$ periods is dominant in the northeastern Pacific. In the eastern Pacific warm pool at the center of the ETP, temporal variability at any scale is relatively low. ENSO warm (El Niño) and cold (La Niña) events have had a variety of effects on marine populations and ecosystems, but these effects are generally followed by recovery within a few years. El Niño effects such as mortality or reproductive failure are most severe on populations dependent on local feeding or breeding grounds in coastal waters or around islands. Decadal variability has also caused change in populations and ecosystems. Most of these effects have been observed in the California Current, Gulf of Alaska, and other well studied regions of the Pacific. The 1976-1977 phase change or 'regime shift' is the most well known case of decadal variability. It affected the physical environment throughout the Pacific Ocean and had major effects on North Pacific ecosystems. No regime shift has been detected in the ETP since 1977. However, ENSO variability continues, an unusually persistent warming prevailed in the early 1990s and the thermocline has shoaled in the ETP warm pool area since 1980. Potential population effects on dolphin stocks are discussed. Interaction of environmental changes with other factors, such as fishery stress or mortality, may also induce population effects.
\end{abstract}

KEY WORDS: Eastern tropical Pacific Ocean · Decadal variability · ENSO - Climate change · Regime shift

Resale or republication not permitted without written consent of the publisher

\section{INTRODUCTION}

Oceanographers have found that the ocean environment varies over every time scale that can be resolved, as instrumental records have been extended, more accurate proxy records have been retrieved and calibrated, and these records have been analyzed with new statistical tools. The ocean environment in the eastern tropical Pacific Ocean (ETP) varies seasonally, interannually and on longer time scales (decadal and climate change). Sorting out variability at these scales

*Email: pfiedler@ucsd.edu is necessary when attempting to detect environmental change and to interpret or predict its effects.

Seasonal variability exceeds interannual variability at the ocean surface, except within 5 to $10^{\circ}$ of the equator in the Pacific (Fig. 1; also Delcroix 1993). Interannual variability is relatively strong in the eastern equatorial Pacific due to the natural cycle of the oceanatmosphere system called the El Niño Southern Oscillation (ENSO). Variability in the equatorial Pacific, particularly in the central and western Pacific, is dominated by the ENSO with periods of 2 to $7 \mathrm{yr}$. Seasonal variability associated with the wind-driven equatorial cold tongue is strong in the eastern equatorial Pacific. 
This review will consider seasonal variability only to provide a perspective for patterns of interannual variability.

Instrumental records of environmental variables with sufficient temporal coverage to resolve interannual and longer-term variability either at a point or in a region of the ocean do not begin until about 1950 in the eastern Pacific, except for a few shore stations on the US coast (see www.mlrg.ucsd.edu/shoresta/index.html). Coral records of isotope ratios have the potential to extend records of interannual and annual variability back beyond instrumental records, but interpretation
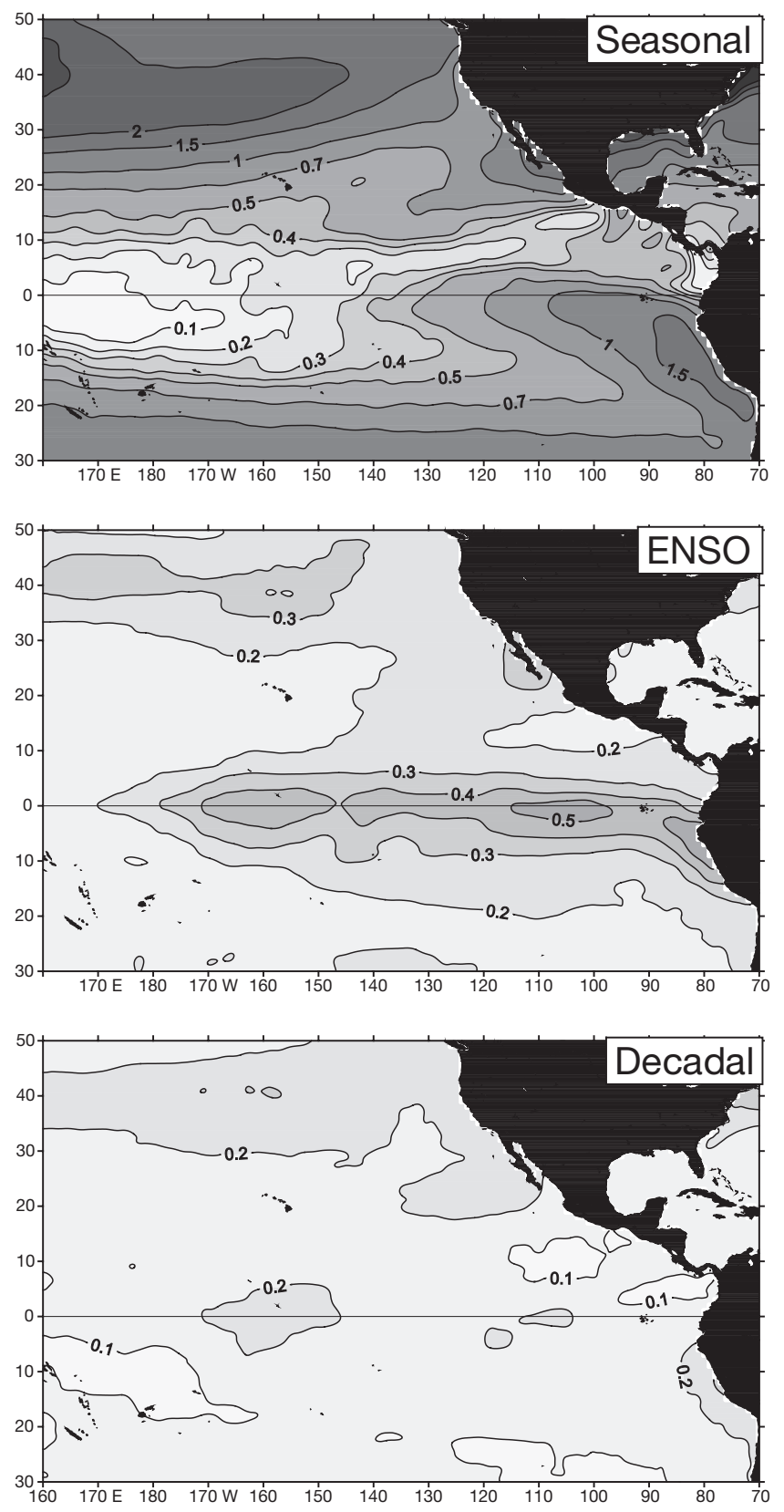

of temperature, salinity, biological and methodological effects is sometimes ambiguous. The longest published records for ETP cores extend to about 1600 (Gagan et al. 2000). Interannual and decadal variability in eastern equatorial Pacific (NINO3 region) SST are illustrated in Fig. 2 (Mann et al. 2000). The NINO3 record has been reconstructed back to 1650 using proxy data from tree rings, corals, sediments and ice cores. Changes that have occurred over the last few decades are grossly similar to changes that have occurred for centuries, although modulations of the details will be discussed below.
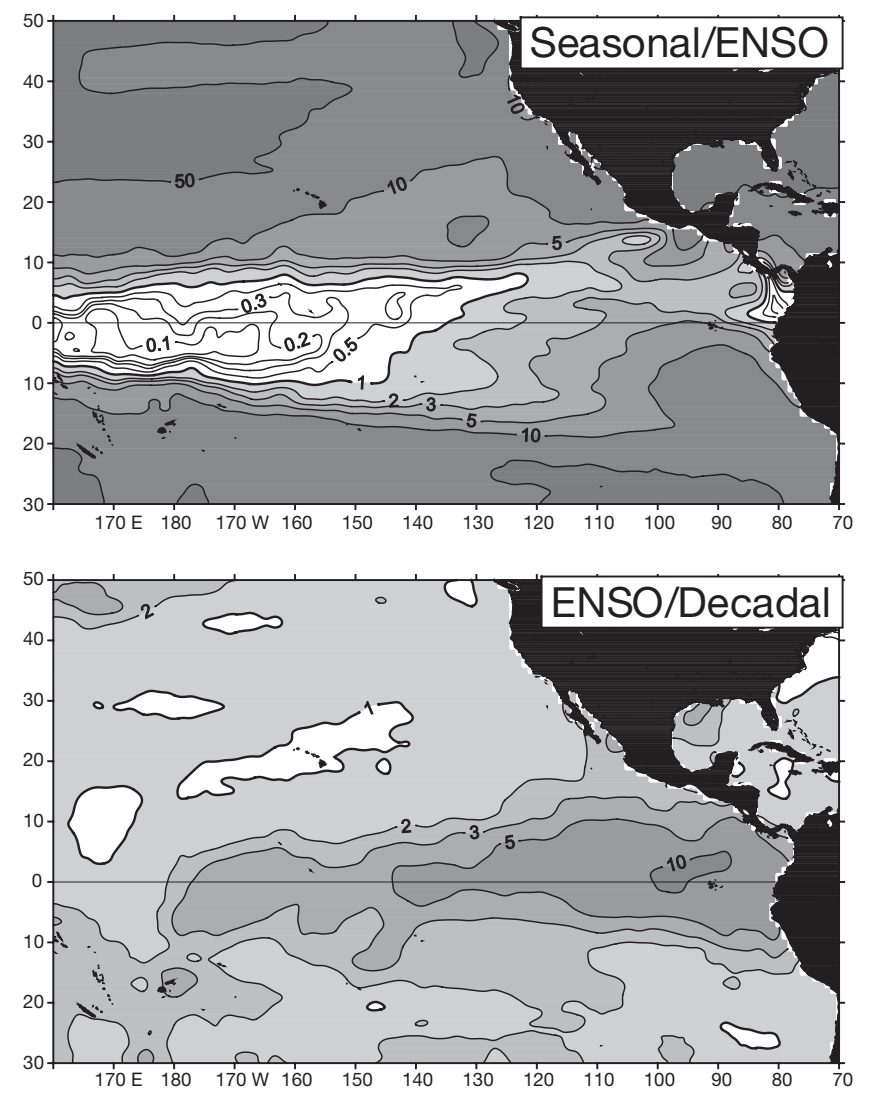

Fig. 1. Variances of sea surface temperature from 1901 to 2001 (expressed as $\mathrm{SD},{ }^{\circ} \mathrm{C}$ ) summed in 3 spectral bands (left): seasonal (0.98 to $1.02 \mathrm{yr}$ ), ENSO (1.8 to $7.2 \mathrm{yr}$ ) and decadal (9.2 to $50.5 \mathrm{yr}$ ). Ratios of seasonal/ENSO and ENSO/decadal variances (right). Data from the UK Meteorological Office Global Sea-ice SST (GISST, v. 2.3b) data (Parker et al. 1995), obtained from British Atmospheric Data Centre 


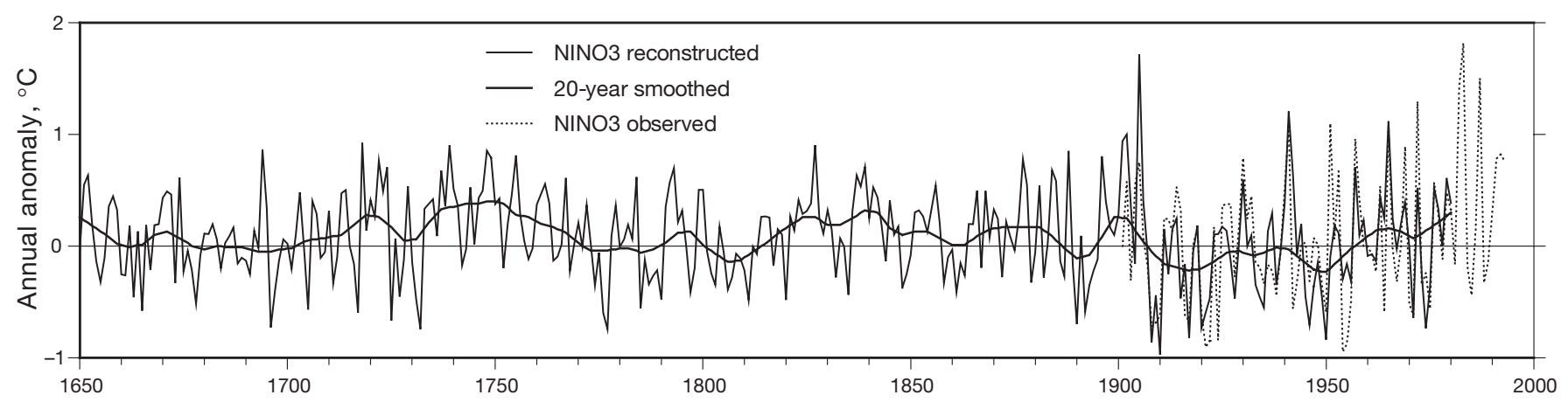

Fig. 2. Annual sea surface temperature variability in the eastern equatorial Pacific since 1650 (Mann et al. 2000). '20-year smoothed' is the NINO3 reconstructed series smoothed by local regression (LOESS) within a 20 yr span

Climate variability in the ocean, meaning variability on interannual and longer time scales, has been treated in 2 ways (Schwartzlose et al. 1999). For the purpose of this review, these 2 approaches to analyzing climate variability will be labeled as 'spectral' and 'regime'. The spectral approach uses statistical methods of time series and spectral analysis to decompose variability into trends, periodic oscillations and random fluctuations. Moron et al. (1998) list 32 studies of global SST variability published between 1990 and 1996, all utilizing various statistical techniques to extract multiple time scale signals (the spectral approach). Long-term trends in such analyses, with the possible exception of global warming forced by greenhouse gasses, most likely represent low frequency oscillations that are not resolved by short time series (Ware \& Thomson 2000). The regime approach uses different statistical methods to break up time series into 'regimes' characterized by relatively stable means and patterns of physical and biological variables, separated by rapid climate or regime shifts of synchronous change in these variables (Ebbesmeyer et al. 1991, Beamish et al. 1999). There are also statistical methods, involving empirical orthogonal function or principal component analysis, that make no assumption about the spectral or regime-like nature of temporal patterns (cf. Zhang et al. 1997). The spectral and regime approaches to analyzing climate variability have both provided useful results. Both of these approaches will be reviewed and applied here.

This paper is intended to be a general review of interannual (ENSO and longer-term) variability in the ETP, and the biological and ecosystem effects of such variability. Environmental variability and effects in the ETP will be compared to what is known about more well known systems in the northeast Pacific. This review, and subsequent new analyses of environmental time series, will be focused somewhat on potential impacts of environmental change on cetaceans. Consideration of this issue is part of the research mandated to the US National Marine Fisheries Service by The International Dolphin Conservation Program Act of 1997 (IDCPA, see www.nmfs.noaa.gov/prot_res/PR2/ Tuna_Dolphin/IDCPA.html).

\section{ENSO VARIABILITY}

The ENSO is an irregular fluctuation involving the entire tropical Pacific Ocean and global atmosphere (Philander 1999). ENSO itself consists of an unstable interaction between sea surface temperature (SST) and atmospheric pressure. It results in variations in winds, rainfall, thermocline depth, circulation and ultimately in biological productivity, and in the feeding and reproduction of fish, birds and marine mammals. The physics of ENSO have been reviewed elsewhere (Philander 1990, 1999, Neelin et al. 1998, Wallace et al. 1998) and will not be detailed here. Briefly, El Niño events occur at intervals of 2 to $7 \mathrm{yr}$ and are characterized by weak trade winds, a deep thermocline and warm SSTs in the eastern equatorial Pacific. El Niño's opposite phase, La Niña, is characterized by strong trade winds, a shallow thermocline and cool SSTs.

ENSO variability has been documented in the written record over 100s of years (Quinn et al. 1987, Enfield 1992). It is evident in paleoclimatic records, with slight changes in amplitude or frequency, over 1000s of years (Diaz \& Markgraf 1992, 2000). For example, Rodbell et al. (1999) showed that the frequency of ENSO variability increased progressively over the period from about 7000 to 5000 yr ago, and archaeological evidence suggests that El Niño events were either absent or very different from today for several millennia prior to that time (Sandweiss et al. 2001).

Since 1970, El Niños occurred in 1972-73, 1982-83, 1986-87 and 1997-98, with weak events in 1976-77 and 1991-92 (Fig. 3). La Niñas occurred in 1970-71, 1973-74, 1975-76, 1988-89 and 1998-99 (Larkin \& Har- 


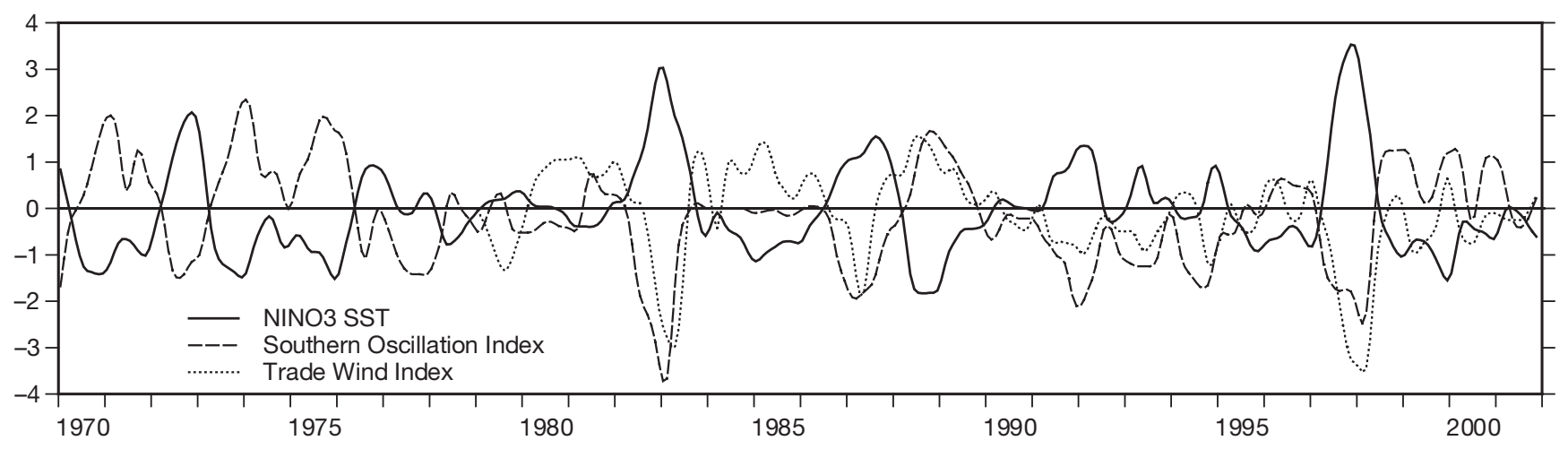

Fig. 3. ENSO indices from 1970 to 2001 . NINO3 SST anomaly $\left(5^{\circ} \mathrm{S}\right.$ to $5^{\circ} \mathrm{N}, 150$ to $90^{\circ} \mathrm{W}$, $\left.{ }^{\circ} \mathrm{C}\right)$; Southern Oscillation Index (Tahiti to Darwin sea level pressure, standardized); Trade Wind Index (850 mbar easterly wind velocity, $5^{\circ} \mathrm{S}$ to $5^{\circ} \mathrm{N}, 135$ to $120^{\circ} \mathrm{W}$, standardized). Monthly values were obtained from NOAA/NCEP/Climate Prediction Center (www.cpc.ncep.noaa.gov/data/indices) and smoothed using method of running medians known as 4(3RSR)2H (S-Plus 2000, MathSoft)

rison 2001). Variability in the tropical Pacific was relatively low during the early 1990s, except for a weak El Niño in 1991 to 1992. Although this period was initially interpreted as evidence of global warming (Trenberth \& Hoar 1996), it has since been interpreted as natural decadal to centennial scale variability (Rajagopalan et al. 1997). Latif et al. (1997) described this prolonged period of warm surface temperatures and weak trade winds as 'anomalous' because the decadal mode of variability was stronger than the ENSO mode in the tropical Pacific at this time. Goddard \& Graham (1997) interpreted this period as a series of 3 El Niño events that were not fully realized, due to a persistent warm patch in the central equatorial Pacific that interfered with the ocean-atmosphere interaction that normally results in oscillations between warm and cold states. Fedorov \& Philander (2000) described the early 1990s as simply a period of persistent warm background conditions.

\section{DECADAL VARIABILITY}

Many global and regional studies of marine environmental time series (temperature, atmospheric pressure, winds, sea level, etc.) have been published since 1990, both to evaluate the existence of a global warming signal and to assess possible effects of climate variability on fisheries and ecosystems. For this review, 'decadal' refers to variability on a scale longer than ENSO, roughly in the range of 10 to $30 \mathrm{yr}$. Although some authors use the word 'interdecadal', either as a synonym for 'decadal' or to indicate the periodicity of decadal scale regimes or phases, it will be translated to 'decadal' here. In general, decadal variability in the Pacific has a smaller amplitude than ENSO variability, but there are regional exceptions to this rule. A brief review of some of these studies will show how variability in the ETP compares with variability in the North Pacific at ENSO and decadal time scales. Note that variability at ENSO scales of 2 to $7 \mathrm{yr}$ is not necessarily directly related to the ENSO.

In a typical study of global SST variability, Moron et al. (1998) found that ENSO scale variability at periods of about 5, 4 and $2 \mathrm{yr}$ dominated SST variability in the Pacific from 1901 to 1994. While they detected longer scale near-decadal oscillations in the Atlantic and Indian Oceans, none was statistically significant in the Pacific. This result may simply reflect the relative magnitude of variability at the 2 time scales. Latif et al. (1997) found that global SST variability $\left(30^{\circ} \mathrm{S}\right.$ to $60^{\circ} \mathrm{N}$ from 1949 to 1991) could be explained by 3 modes: ENSO (25\%, strongest in the eastern equatorial Pacific), decadal $(10 \%$, strongest in a horseshoe pattern centered in the western equatorial Pacific and extending northeast and southeast) and a linear trend (or unresolved ultra-low-frequency variability). Linear trends were relatively small in the ETP and did not explain much SST variability.

Several studies have found different characteristic time scales of variability for the tropical and North Pacific. Giese \& Carton (1999) analyzed 1950 to 1993 Pacific Ocean MBT and XBT observations and concluded that ENSO variability (1 to $5 \mathrm{yr}$ ) of SST is greatest in the tropics, while decadal variability ( $>5 \mathrm{yr}$ ) is greatest in the midlatitude North Pacific. Zhang et al. (1998b) analyzed 1950 to 1993 data from the Comprehensive Ocean-Atmosphere Data Set (COADS) and found that ENSO variability at periods of 4 and $2 \mathrm{yr}$ dominated interannual variability of SST in the tropical Pacific, but decadal variability ( $>5 \mathrm{yr}$ ) dominated in the central North Pacific. In the tropical and North Pacific as a whole, decadal variability accounted for only $1 / 3$ as much variance as did ENSO variability. An early 
study by Ghil \& Vautard (1991) had generalized this pattern for global temperature time series: interannual oscillations (5 to $6 \mathrm{yr}$ ) were related to global aspects of ENSO, and decadal oscillations (16 to 21 yr) were associated with extratropical changes.

In a longer record (1870 to 1999) of SST monthly anomalies in the eastern equatorial Pacific (NINO3), Mestas-Nuñez \& Enfield (2001) found that ENSO accounted for $79 \%$ of the total variability. The residual variability was dominated by the decadal time scale, but also included higher frequency variability. Thus, ENSO scale variability was much greater than longer scale variability in this part of the ETP. For the North Pacific $\left(>20^{\circ} \mathrm{N}\right)$, Ware (1995) found that SST variability was dominated by 20 to 25 yr periodicity, resulting in 7 warm periods and $6 \mathrm{cool}$ periods (each 11 yr long or decadal scale) since 1850. This alternation between warm and cold phases of about $10 \mathrm{yr}$ is now indexed by the Pacific Decadal Oscillation (PDO), defined as the leading principal component of North Pacific monthly SST variability (Mantua et al. 1997).

Studies of global SST variability have further elaborated regional and basin scale differences. Enfield \& Mestas-Nuñez (2000) performed a complex empirical orthogonal function analysis of global SST monthly anomalies from 1856 to 1991 . About $45 \%$ of the global low passed (>1.5 yr) SST variability was contained in 4 modes: ENSO $(17 \%$, strongest in the eastern equatorial Pacific), global warming $(15 \%$, strongest in the subtropical Pacific off California), 'Pacific interdecadal' (8\%, strongest in the central North Pacific) and 'Atlantic multidecadal' (5\%, strongest in the North Atlantic). None of the 4 modes was manifested to a high degree in the region of the eastern Pacific warm pool of the ETP. Similar results were found by Tomita et al. (2001), who identified 7 global 'centers of action' of decadal scale variability: variability was low in the eastern Pacific warm pool, although centers of high variability were located in the central equatorial Pacific, and off Peru and Baja California.

Analyses of longer time series resolve variability at scales longer than decadal, as expected. Chao et al. (2000) tentatively identified a 70 yr mode in Pacific SST variability. Minobe $(1997,1999)$ has shown that PDO variance has 2 broad-band peaks at periods of 15 to 25 and 50 to 70 yr. Ware \& Thomson (2000) analyzed 400 yr time series of tree ring records that were assumed to represent air temperatures from the west coast of America and found 3 characteristic time scales: ENSO (2 to $8 \mathrm{yr}$ ), 'interdecadal' (20 to $40 \mathrm{yr}$ ) and 'multidecadal' (60 to $80 \mathrm{yr}$ ). In this study, the ENSO cycle was the most prominent time scale, and was related to equatorial ENSO variability through both atmospheric teleconnections and coastal-trapped internal Kelvin waves. The 'multidecadal' signal modulates the ampli- tudes and frequencies of both the ENSO and 'interdecadal' signals.

Modulation of ENSO variability on the decadal time scale has been found in studies of tropical Pacific records. Mestas-Nuñez \& Enfield (2001) found that the late 1970 s climate shift that warmed the eastern equatorial Pacific (NINO3 region) by about $0.5^{\circ} \mathrm{C}$ was also characterized by increased interannual variance through the 1980s and 1990s (see Fig. 6c further below). Analysis of an 1893 to 1994 coral record from Clipperton Atoll (within the eastern Pacific warm pool area) shows both ENSO and decadal scale variability closely related to instrumental Southern Oscillation Index (SOI) and PDO records from recent years (Linsley et al. 2000). Reduced ENSO variability is evident between 1925 and the mid-1940s. An \& Wang (2000) found that the dominant period of SST variability in the central and eastern equatorial Pacific (NINO34 region) shifted from $3.3 \mathrm{yr}$ during 1967-1973 to 4.2 yr during 1980-1993. Setoh et al. (1999) found a similar increase in the period of ENSO in the equatorial Pacific during the late 1970s, but also found slight changes in the spatial pattern of the ENSO signal. However, Fedorov \& Philander (2000) argued that apparent changes in ENSO may simply reflect decadal scale changes in the background state (climatology) against which El Niño and La Niña are measured. Spectral analysis of a composite record of ENSO events since $622 \mathrm{AD}$ showed that the period of ENSO variability has varied, within a range of 1.5 to $10 \mathrm{yr}$, in cycles of 90, 50 and $23 \mathrm{yr}$ (Anderson 1992). None of the studies cited above found a change in ENSO variability after the late 1970s.

The regime approach to climate variability focuses on abrupt steps rather than oscillations in climate records, although there is evidence of both types of variability (Miller et al. 1994). This approach was prompted by a remarkable 1976-77 winter in the North Pacific: a deeper and eastward-shifted winter Aleutian low pressure system increased winds, advected warmer and moister air along the west coast of North America and colder air over the North Pacific, warmed surface waters along the west coast of North America and Alaska, and cooled surface waters in the central North Pacific. Associated changes in storm tracks, rainfall, sea ice, heat fluxes and ocean currents were observed (Trenberth \& Hurrell 1994). Ebbesmeyer et al. (1991) assembled a composite time series of 40 physical and biological variables to illustrate a distinct step-like 'regime shift' in the winter of 1976-77. Clarke \& Lebedev (1996) showed decadal scale variability in equatorial Pacific trade winds, with a major weakening beginning in 1970 (before the 1976-77 North Pacific regime shift).

'Regime shift' has been a prevalent term in the literature describing and analyzing variability in North 
Pacific fisheries and ecosystems published during the 1990s (cf. Francis et al. 1998, Anderson \& Piatt 1999, Karl et al. 2001). However, the 1976-77 'regime shift' is now interpreted by some as a phase change in a decadal scale oscillation lasting from about 1976 to 1988 (Trenberth \& Hurrell 1994, Miller et al. 1994). Hare \& Mantua (2000) analyzed 100 physical and biological time series from the northeast Pacific, covering the period from 1965 to 1997 , and found regime shifts in 1977 and 1989. The 1989 changes were not a simple reversal of the 1977 changes, and were more pronounced in the biological than in the physical time series. Ware \& Thomson (2000) interpreted their $400 \mathrm{yr}$ time series from the 'regime' point of view and showed major climate 'regime shifts' (warm-to-cold as in the 1940 s or cold-to-warm as in the 1970s) at intervals of about $30 \mathrm{yr}$ throughout the record. Minobe (1997) identified climate regimes of 25 to $35 \mathrm{yr}$ in North Pacific time series, with regime shifts in about 1890, 1923, 1948 and 1977. Chao et al. (2000) found a 15 to 20 yr decadal oscillation in Pacific SSTs with phase transitions in 1924-25, 1941-42, 1957-58 and 1976-77. Biondi et al. (2001) and Gedalof \& Smith (2001) extended the PDO record back to about 1600 with tree ring chronologies and found pronounced decadal scale oscillations, comparable to the 1976-77 'regime shift', throughout the records.

The 'regime' and 'spectral' views of climate variability may be entirely compatible: repeated shifts between 2 regimes or phases at more or less regular intervals are an oscillation. Miller \& Schneider (2000) concluded that 'the presently limited observations cannot be used to discriminate confidently oscillatory from step-like models' of decadal variability in the North Pacific. Watanabe \& Nitta (1999) showed that 'the sharpness of decadal changes in 1989 (and winter 1977) arises from synchronous phase shifts of decadal variations over the Pacific Ocean and quasi-decadal variations over the North Atlantic'. Indeed, LluchBelda et al. (2001), in a re-analysis of long-term physical and biological variability in the California Current, used the term 'trend reversal' in place of 'regime shift', to emphasize that regimes are stable trends (warming or cooling) rather than stable states (warm or cool periods). These and other authors have related biological 'regimes' to the decadal climate variability summarized above (see 'Biological effects of decadal variability in the Pacific').

Explanation of climate variability in the ETP is beyond the scope of this paper. However, a few summary comments are relevant. As discussed above, ENSO is an internal cycle of the ocean-atmosphere system that has been active at periodicities of 2 to $7 \mathrm{yr}$ for at least the past 5000 yr. Decadal scale variability resembles ENSO scale variability in spatial pattern and, like
ENSO, it may involve coupled feedback between the atmosphere and ocean. Tropical and North Pacific decadal variability are negatively correlated and forcing may occur in either direction (Pierce et al. 2000). Zhang et al. (1998a) argued that decadal variability in the tropics must be forced by extratropical decadal variability because no internal mechanism or process has been identified that could maintain a tropical decadal oscillation. Trenberth \& Hurrell (1994) concluded that atmosphere-ocean feedbacks emphasize decadal relative to interannual (ENSO) variability in the extratropics. Likewise, Giese \& Carton (1999) concluded that, since 'both the decadal and interannual anomaly patterns appear to result from the same basic climate phenomenon, ...ENSO is the equatorial manifestation of interannual changes in the atmospheric circulation over the entire Pacific Ocean, and decadal variability is the midlatitude manifestation'.

\section{BIOLOGICAL EFFECTS OF ENSO VARIABILITY IN THE PACIFIC}

Biological effects of recent El Niño events in the Pacific have been documented and explained primarily for phytoplankton and commercial fish stocks. Barber \& Chavez $(1983,1986)$ and Barber et al. (1985) summarized the effects of the 1982-83 El Niño in the eastern equatorial and Peru upwelling systems: deepening of the thermocline, and thus the nutricline, resulted in decreased primary production that ultimately affected survival, reproduction and distribution of higher trophic level organisms. Coastal upwelling continued along coastal Peru, but the thermocline was depressed below the source depth of upwelled water so that only warm, nutrient-poor waters were upwelled (Huyer et al. 1987). Nutrient depletion and reduction of phytoplankton production along the equator was even more pronounced in the 1997-98 event, but the phytoplankton community recovered in about a month after trade winds and upwelling resumed in May 1998 (Strutton \& Chavez 2000). This recovery may have been in response to both resumption of local winddriven upwelling and a shoaling of the thermocline that began in December 1997 (Chavez et al. 1999).

The 1982-83 El Niño had a variety of effects on commercial fish stocks in Peru: hake moved down the continental slope to stay in cooler deep water, shrimp and sardines moved southward so that catches in some areas decreased and in other areas increased, jack mackerel moved inshore in search of euphausiid prey and were subject to high predation mortality there, scallop abundance increased due to enhanced reproductive success in warmer water, and the anchoveta population crashed due to reduced food availability 
for adults and larvae. However, many of these stocks recovered rapidly beginning in late 1983 (Barber \& Chavez 1986).

In the eastern equatorial Pacific, sampling by ships of opportunity showed that El Niño 1982-83 caused a deepening of the thermocline, and a reduction in chl a and copepod abundance (Dessier \& Donguy 1987). Dandonneau (1986), however, concluded that the winter 1982-83 reduction in the equatorial upwelling region was confined to the central equatorial Pacific and that chl a remained high east of $120^{\circ} \mathrm{W}$ in these data. Fiedler et al. (1992) found that changes in thermocline depth and nutrient availability in the ETP resulted in a surface chl a decrease during the 1986-87 El Niño and an increase during the 1988 La Niña. These changes were most pronounced in coastal and equatorial upwelling regions, but were also evident along the countercurrent thermocline ridge north of the equator.

A variety of ENSO effects have been reported on animals other than commercially exploited fish. Changes in zooplankton biomass are often secondary to changes in species composition. For example, euphausiid species shifted distribution along southern Baja California during El Niño 1986-87, so that cold water California Current species were less common and warm water tropical species were more common (Gómez-Gutiérrez et al. 1995). Zooplankton biomass off northern Chile did not change during El Niño 1997-98, although the relative abundance of small sized copepods increased (González et al. 2000). Two Panamanian coral species were eliminated by the 1982-83 El Niño warming (Glynn \& De Weerdt 1991); these species were unusual in that they were highly sensitive to warming and confined to warm shallow water in a small geographic area. Warming events in the northeast Pacific, whether or not they are linked to equatorial El Niños, have changed migration patterns of bluefin tuna and sockeye salmon, increased Pacific herring recruitment and increased body weight of mature sockeye salmon (Mysak 1986). Skipjack tuna in the western Pacific migrate zonally as the warm pool expands and contracts, and optimal feeding grounds shift in response to ENSO (Lehodey et al. 1997).

ENSO effects on seabirds have been relatively easy to observe at island breeding colonies. The seabird community on Christmas Island, in the central equatorial Pacific, suffered total reproductive failure from flooding rains in late 1982 and subsequent disappearance of adults due to reduced food availability; however, the adults returned to breed in the following year (Schreiber \& Schreiber 1984). Throughout the tropical and northeastern Pacific in 1982-83, seabird populations experienced breeding failures, mass mortalities and migrations in search of food (Ainley et al. 1988), although a few species were not affected.

Body weight of Galapagos penguins increased during La Niña 1971 and decreased during El Niño 1972, indicating short-term response to food availability, but the population suffered $77 \%$ mortality during the 1982-83 event and had not recovered by 1997 (Dee Boersma 1998). Blue-footed booby reproductive attempts failed and breeding colonies were abandoned during the 1986-87 El Niño, apparently in response to reduced availability of sardines, but several other species were not affected (Anderson 1989). Guanoproducing seabirds in coastal Peru have consistently experienced adult mortality and decreased reproductive success during El Niño events; these are shortterm population effects, resulting from reduced availability of anchoveta (Tovar et al. 1987, Crawford \& Jahncke 1999). All 15 species of seabirds nesting on the Galapagos Islands stopped breeding or experienced reduced reproductive success during El Niño 1982-83, but resumed breeding the following year (Valle et al. 1987). Several seabird species experienced reduced breeding success in response to food shortage during warm water events in the California Current (Ainley et al. 1995, Sydeman et al. 2001). Pelagic seabird surveys have shown changes in the relative abundance of less common species, but not the dominant species, during El Niño and La Niña events in the eastern equatorial Pacific (Ribic et al. 1992). Such changes may be explained by shifts in distribution between the equatorial and subtropical water masses covered by these surveys. In general, seabirds that forage in upwelling areas of the ETP and Peru Current suffer reproductive failure and mortality due to food shortage during El Niño events. However, other species that forage in areas less affected by El Niño, for example the warm pool, may be relatively unaffected (L. Ballance pers. comm.).

Mortality or other population effects of El Niño on marine mammals have been observed in coastal ecosystems. Manzanilla (1989) observed a 1983 'El Niño mark' in the teeth of mature female Peruvian dusky dolphins and suggested that the mark resulted from low foraging success for the preferred prey, anchoveta, which became unavailable during the 1982-83 El Niño. Consistent with this inference, no such marks were observed in other dolphin species that consume other prey. However, a much lower incidence of marks in immature female and in male dusky dolphins could not be explained. Galapagos pinnipeds suffered great mortality in 1982-83, especially in younger year classes, and reduced pup production due to reduced food availability (Trillmich \& Limberger 1985). Peruvian pinnipeds were affected by the reduced availability of anchoveta in 1983 (Majluf \& Reyes 1989). 
Ramirez (1986) observed diet changes and reduced feeding success of Bryde's whales off Peru during El Niño 1982-83.

Shane (1995) argued that the reduced availability of squid around Santa Catalina Island during the 1982-83 El Niño triggered a competitive displacement of pilot whales by Risso's dolphins. ENSO variability has had short-term effects on pup production and adult distribution of central California pinnipeds, probably through food availability, but no long-term population effects (Sydeman \& Allen 1999). These authors, in fact, concluded that oceanographic effects 'do not appear to confound interpretations of population recovery'. However, El Niño reductions in prey availability have caused reduced pup production and increased pup mortality at southern California Channel Island pinniped breeding colonies; the severe 1982-83 and 1997-98 events also caused juvenile and adult mortality, resulting in population changes lasting several years and temporary interruption of the long-term recovery of depleted populations (DeLong \& Melin 2000).

Large whales are able to move in response to El Niño perturbations. An unusual coccolithophore bloom in the Bering Sea during El Niño 1997-98 was exploited by zooplankton and baleen whales that moved onto the middle shelf to feed on the krill (Tynan 1999). El Niño warming inhibits migration of gray whales to southernmost Baja California calving grounds, but the whales continue to utilize more northern areas (Gardner \& Chávez-Rosales 2000).

A generalization about ENSO effects on higher organisms was made by Sharp (1992): 'close examination of the facts has shown that the effects of individual El Niño events can be devastating, but within a short time, the majority of the effects fade and life goes on. ENSO cycles are perturbations of the most important global climate pattern, the seasonal cycle. Ocean and atmosphere are sufficiently interactive on daily, seasonal and interannual bases that ocean inhabitants have had to adopt responsive survival strategies into their life histories to cope with these frequent environmental processes (and) to persist'. An unusual example of such an adaptive response is the ability of Galapagos marine iguanas to shrink in body size and thus, increase energy efficiency, to compensate for El Niño reductions in food availability (Wikelski \& Thom 2000).

\section{BIOLOGICAL EFFECTS OF DECADAL VARIABILITY IN THE PACIFIC}

Biological effects of decadal scale climate variability have been observed and explained, but only when time series from commercial fisheries or exceptionally long research programs are available. Data collected since 1949, in California coastal waters for the CalCOFI program have shown interannual variability of physical and biological variables that is at least as great as seasonal variability. Interannual ENSO scale variability of zooplankton biomass appears to be driven by variations in transport from the north (McGowan et al. 1996). In contrast, a $70 \%$ decrease in macrozooplankton biomass and a surface layer warming of up to $1.5^{\circ} \mathrm{C}$ from 1951 to 1993 off southern California has been explained by internal processes (Roemmich \& McGowan 1995). Increased stratification has inhibited upwelling and mixing of deep water and thus, local productivity within the system. McGowan et al. (1998) lamented that 'the role of climatic variation in regulating marine populations and communities is not well understood... probably because of the mismatch between the scales of important atmospheric and oceanographic processes and the spatial and temporal dimensions of biological research programs'.

Yet, studies reviewed below have demonstrated population effects of climate variability. Most of these studies view climate variability in terms of regimes, because variability of North Pacific stocks and ecosystems was initially described in terms of biological regimes in the 1990 s.

North Pacific ocean climate changes in 1977 (intensified Aleutian Low) and 1989 (back to near-average Aleutian Low, Hare \& Mantua 2000) affected the abundance and ocean survival of salmon, the distribution and spawning behavior of hake and sardine, and recruitment of several groundfish species in the eastern North Pacific (McFarlane et al. 2000). Beamish et al. (1999) argue that these climate regime shifts and accompanying fluctuations in fish stocks have been occurring since at least 1600. Hollowed et al. (2001) reviewed time series of catch and recruitment for Northeast Pacific fish stocks and found evidence that some stocks were affected by the 1976-77 and 1988-89 phase changes in the PDO, but that others were positively affected by ENSO scale warm conditions on the eastern side of the North Pacific ('Niño North').

Decadal scale variability of the Aleutian Low affected recruitment of Japanese sardine and can explain variability of catch back to 1600 (Yasuda et al. 1999). Declines of both the Japanese and California sardine stocks during the 1940s were caused by longterm cooling of surface waters (Lluch-Belda et al. 1989). Recovery of California and Peru stocks during the 1970 s was related to warming through effects on spawning (Lluch-Belda et al. 1992). Lluch-Cota et al. (1997) combined catch records of Pacific sardine and anchovy stocks into a composite 'regime indicator series' and identified 3 regimes in the period from 1925 
to 1995 , with regime shifts around 1950 and in the late 1970s. Then, using the spectral approach, they showed that the sardine/anchovy regime series is related to global decadal climate variability of surface air temperature.

Francis et al. (1998) reviewed ecosystem effects of the 1976-77 shift in atmospheric dynamics over the northeast Pacific and concluded that phytoplankton, zooplankton and fish production all responded to this change, resulting in substantial ecosystem 'reorganization'. However, the magnitude and even the sign of the response differed between regions. For example, zooplankton biomass increased in the central subarctic Pacific (Brodeur \& Ware 1992, Brodeur et al. 1996), but decreased off Southern California (Roemmich \& McGowan 1995) and did not change substantially off Baja California (Lavaniegos et al. 1998). The strongest and most rapid effects appeared at lower trophic levels, although responses were observed at all levels (marine mammals, fish and birds as well as phytoplankton and zooplankton).

Anderson \& Piatt (1999) showed a similar reorganization of the community structure of nekton and their predators in the Gulf of Alaska ecosystem after the late 1970s climate shift: forage species declined and groundfish increased, with negative effects on piscivorous birds and marine mammals. Changes in zooplankton biomass in the subarctic Pacific affected production of nekton, several salmon stocks, and forage availability for birds and mammals (Brodeur et al. 1996, Francis et al. 1998). Effects on salmon occurred in early life history (first year of life in ocean, Francis et al. 1998) and at spawning (Downton \& Miller 1998).

Sydeman et al. (2001) found interannual changes in reproductive success and diet of several species of seabirds breeding in the California Current system from 1969 to 1997 . However, in contrast to the findings of pervasive ecosystem effects of a late 1970s' North Pacific climate shift, only 2 of 11 species showed changes related to a regime shift and these changes occurred in the late 1980s.

Polovina et al. (1995) reviewed decadal variability in wind mixing and resulting changes in primary and secondary production in the subtropical and subarctic North Pacific during the late 1970s. They found that the ecosystem response was different for systems with nutrient- and light-limited phytoplankton production. In the central North Pacific, total chl a increased when stronger and more frequent wind mixing led to greater nutrient input (Venrick et al. 1987). Productivity of the ecosystem at all levels increased, but then decreased when the wind patterns relaxed in the late 1980s (Polovina et al. 1994).

Biological changes cannot always be clearly attributed to ENSO or decadal climate variability; changes associated with an ENSO event may persist long after the event has ended. For example, a persistent reduction in zooplankton biomass along the coast of Peru that occurred in the mid-1970s may have been related to the 1972-73 El Niño (Carrasco \& Lozano 1989). Muck (1989) argued that changes in zooplankton, fish, and predators in the Peru Current ecosystem at this time were all related to the collapse of the anchoveta stock, which was caused by a combination of overfishing and El Niño 1972-73.

Mechanistic explanations of biological effects of climate change have been proposed. For example, decreased upwelling in the California Current system (Bakun 1990) resulted in decreased availability of the euphausiid Thysanoessa spinifera, a preferred prey species, and reduced abundance of Cassin's auklet in the 1980s (Ainley et al. 1996). A $90 \%$ decline in sooty shearwater abundance off southern California from 1987 to 1994, concurrent with a long-term warming, was explained by decreased zooplankton abundance in the inshore feeding grounds (Veit et al. 1996). Ware \& Thomson (1991) showed that sardine and hake biomass off the west coast of North America decreased by a factor of 5 from 1916 to 1942 and found evidence that a strong relaxation in wind-driven upwelling led to lower primary production and thus, lower larval survival and recruitment. Polovina (1996) presented evidence that increased sardine abundance off Japan in 1977 resulted in a lower proportion of juvenile bluefin tuna migrating from the western to eastern Pacific.

\section{EASTERN TROPICAL PACIFIC DECADAL VARIABILITY AND TRENDS}

Long time series of physical or biological variables are not available for the ETP, with the exception of the NINO SST monthly series for equatorial surface waters. The NINO3 eastern equatorial Pacific area abuts the eastern Pacific warm pool, but as illustrated elsewhere in this paper, variability in these 2 areas differs in magnitude, timing and spectral distribution. Short but accurate 22 yr regional time series were derived from monthly data fields produced by the NOAA/NWS National Center for Environmental Prediction's (NCEP) Ocean Data Assimilation System (Behringer et al. 1998). NCEP uses a dynamic ocean model, driven by observed wind stress and surface heat fluxes, to assimilate sparse temperature observations. The observations constrain the model, while at the same time the model interpolates across data gaps using the physics of the model ocean. Surface temperature and thermocline depth $\left(20^{\circ} \mathrm{C}\right.$ isotherm depth in the tropics) were extracted from the resulting 3-dimensional tempera- 


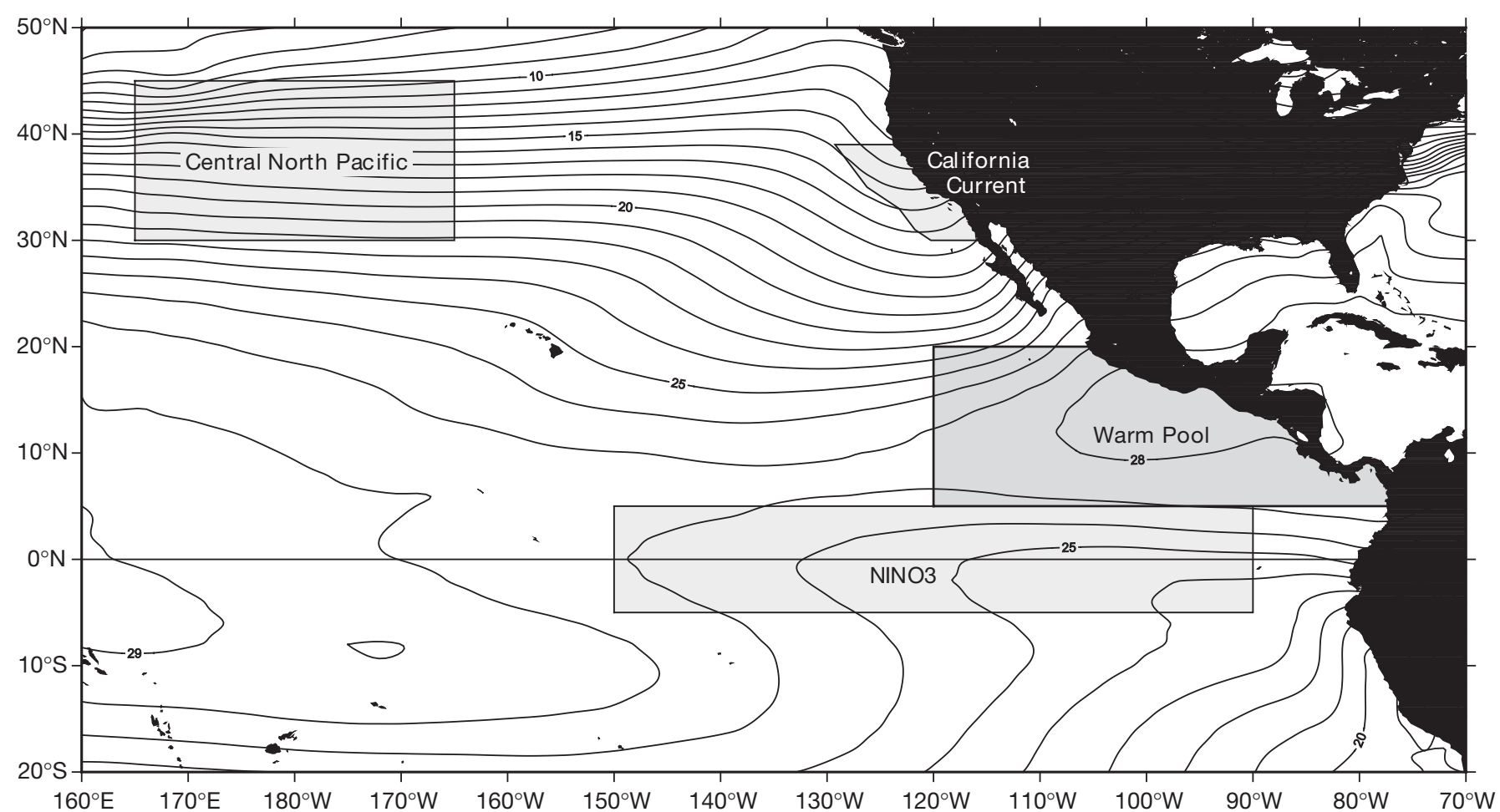

Fig. 4. Surface temperature and thermocline depth time series areas. SST contours are from Reynolds \& Smith (1994)

ture fields and averaged over 4 regions (Fig. 4): (1) ETP warm pool area $\left(5\right.$ to $20^{\circ} \mathrm{N}$, east of $\left.120^{\circ} \mathrm{W}\right)$; (2) NINO3 eastern equatorial Pacific $\left(5^{\circ} \mathrm{S}\right.$ to $5^{\circ} \mathrm{N}, 90$ to $\left.150^{\circ} \mathrm{W}\right)$; (3) California Current (30 to $39^{\circ} \mathrm{N}$, out to $\sim 300 \mathrm{~km}$ from the coast); and (4) central North Pacific (30 to $45^{\circ} \mathrm{N}$, $165^{\circ} \mathrm{E}$ to $\left.165^{\circ} \mathrm{W}\right)$.

Time series of monthly anomalies of SST and thermocline depth were calculated to remove seasonal variability and emphasize interannual and longer scale variability (Fig. 5). ENSO scale variability is dominant in the ETP, with major El Niño events (warm surface temperatures and deep thermoclines) occurring in 1982-83 and 1997-98 and weaker events in 1986-87 and 1991-92. A major La Niña event (cool surface temperatures and shallow thermoclines) occurred in 1987-88 and weaker events in 1984-85 and 1998-99. In general, ENSO anomalies in the ETP warm pool area are about $1 / 2$ the magnitude and several months later than anomalies along the equator. Most ENSO events, but not all (e.g. 1986-87, Lenarz et al. 1995), appear in the California Current. The central North Pacific shows moderate ENSO scale variability, but anomalies there, are of opposite sign than corresponding anomalies in the ETP and California Current.

Cumulative sums of the SST and thermocline depth anomaly time series are presented to visualize the longer-term characteristics of the series. Cumulative sums are used in industrial quality control to detect small and sustained shifts in processes (Manly \& Mackenzie 2000), and have been used to detect climate or regime shifts (Yáñez et al. 1992, Beamish et al. 1999). Climate shifts are marked by changes in slope of the cumulative sum plot. Cumulative sums of the 4 NCEP's surface temperature (Fig. 5b) and thermocline depth (Fig. 5d) time series show evidence of a climate shift in the North Pacific and in the California Current around 1990 (Hare \& Mantua 2000). The ETP warm pool and NINO3 series are dominated by ENSO variability. The only obvious longer-term feature in the 2 ETP series is the relatively constant period from 1990 to 1995. No climate shifts comparable to 1976-77 (or 1990 in the North Pacific) are apparent in the 1980 to 2001 ETP series.

Linear trends of surface temperature in the 1980 to 2001 time series were not statistically significant, except for post-1997 in the central North Pacific (Table 1). Linear trends of thermocline depth in the ETP were statistically significant, indicating an overall shoaling of the thermocline of $7.8 \mathrm{~m}$ in the eastern equatorial Pacific and $6.1 \mathrm{~m}$ in the ETP warm pool since 1980. However, these fitted trends are very sensitive to the length of the series: trends for 1980 to 1998, before the moderate La Niña conditions in 1999-2001, are not significant, and trends for 1984 to 1998 indicate significant deepening of the ETP thermocline. Thus, it is not possible to meaningfully describe 


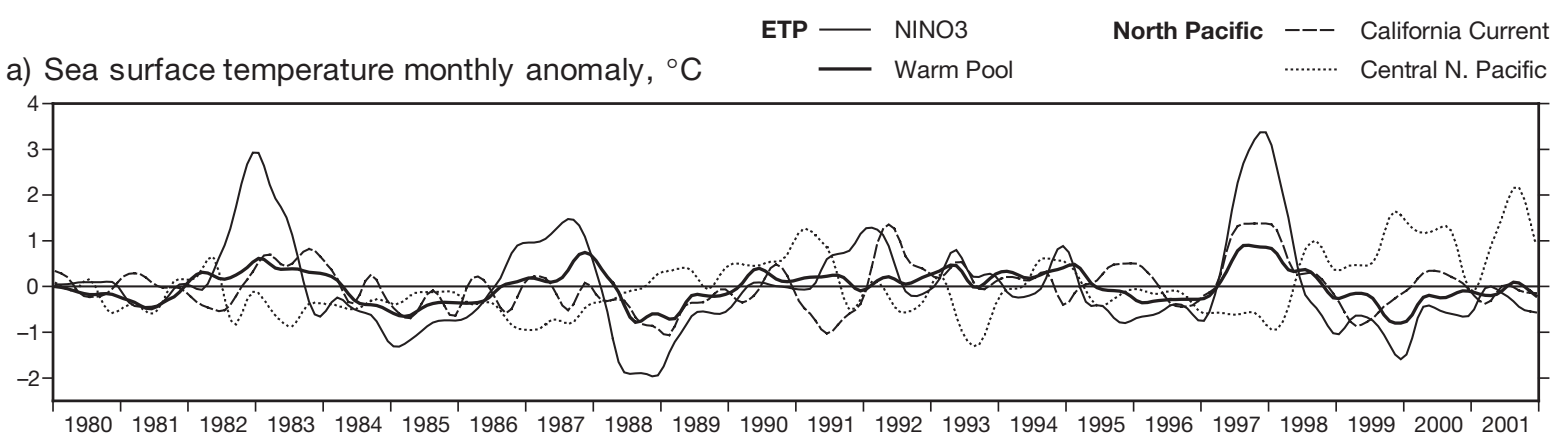

b) Cumulative sum: sea surface temperature monthly anomaly, ${ }^{\circ} \mathrm{C}$

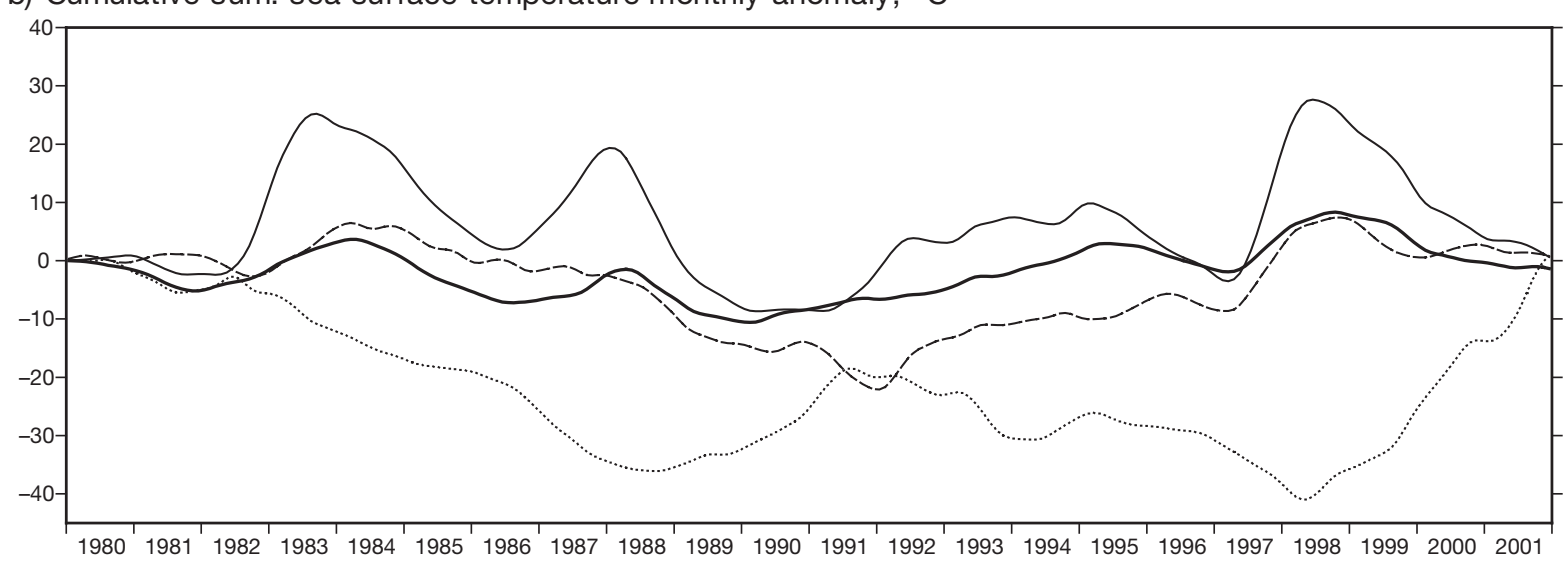

c) Thermocline depth monthly anomaly, $\mathrm{m}$

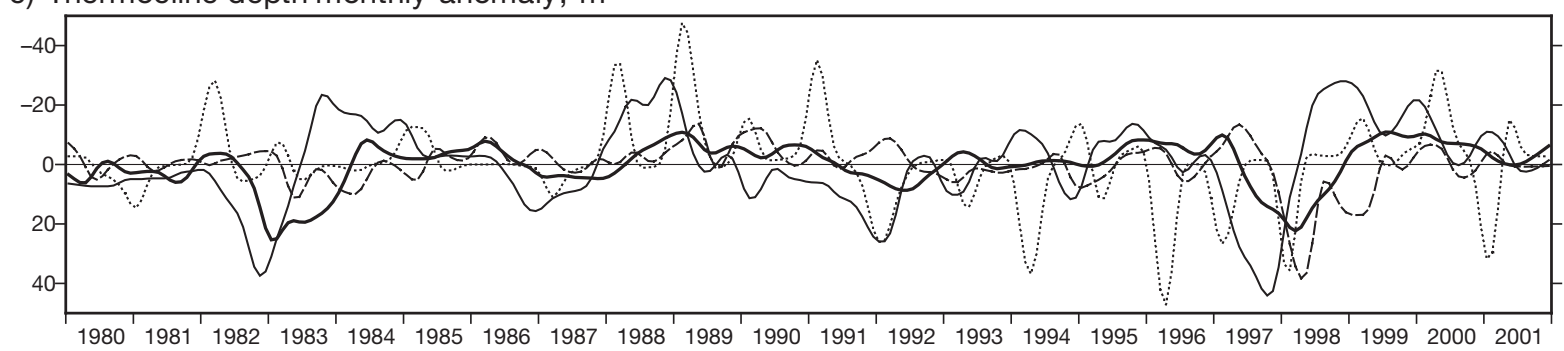

d) Cumulative sum: thermocline depth monthly anomaly, m

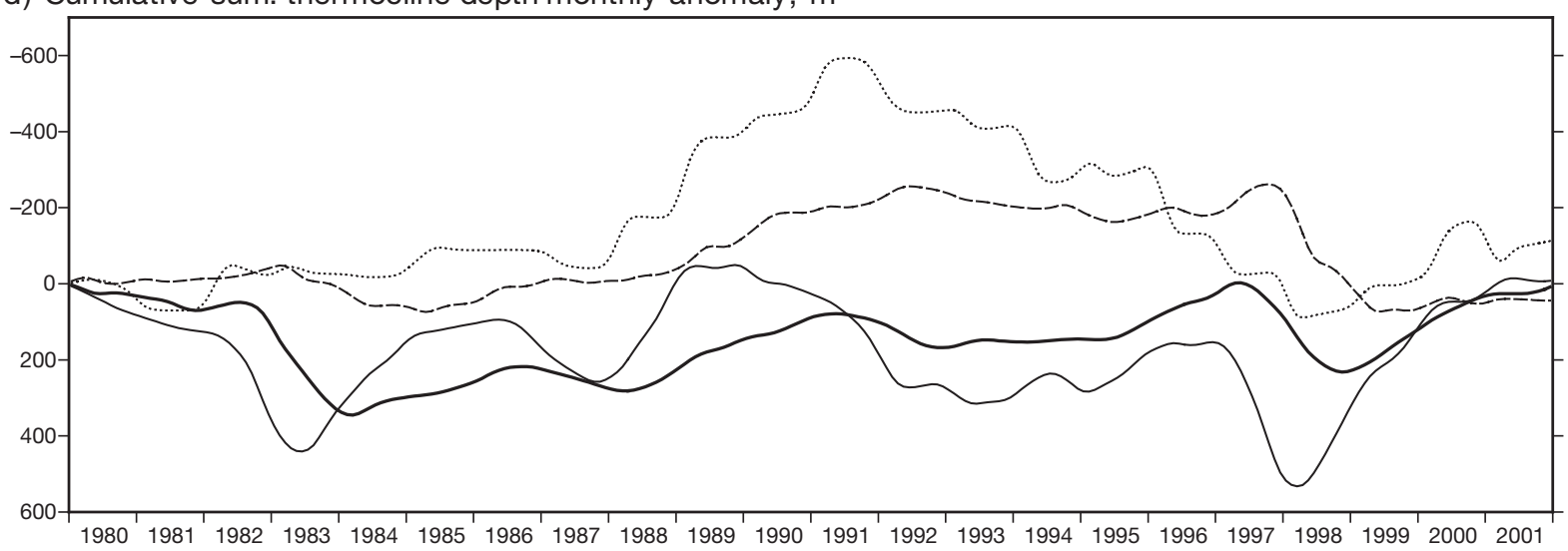

Fig. 5. Time series of 1980 to 2001 SST (a) and thermocline depth monthly anomalies (c) and cumulative sums (b,d) in the eastern tropical Pacific (ETP) and North Pacific regions (see Fig. 4). Thermocline depth calculated at $20^{\circ} \mathrm{C}$ isotherm depth in ETP and depth of maximum temperature gradient in North Pacific. Data from the NCEP (NOAA/NWS/National Center for Environmental Prediction) monthly hindcast fields (Behringer et al. 1998) 


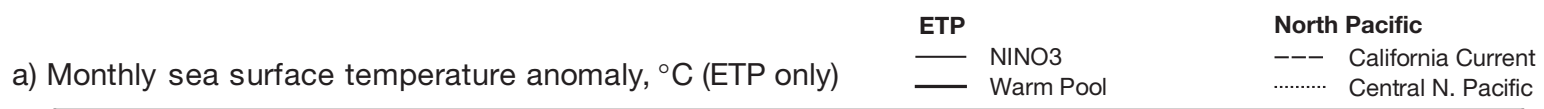
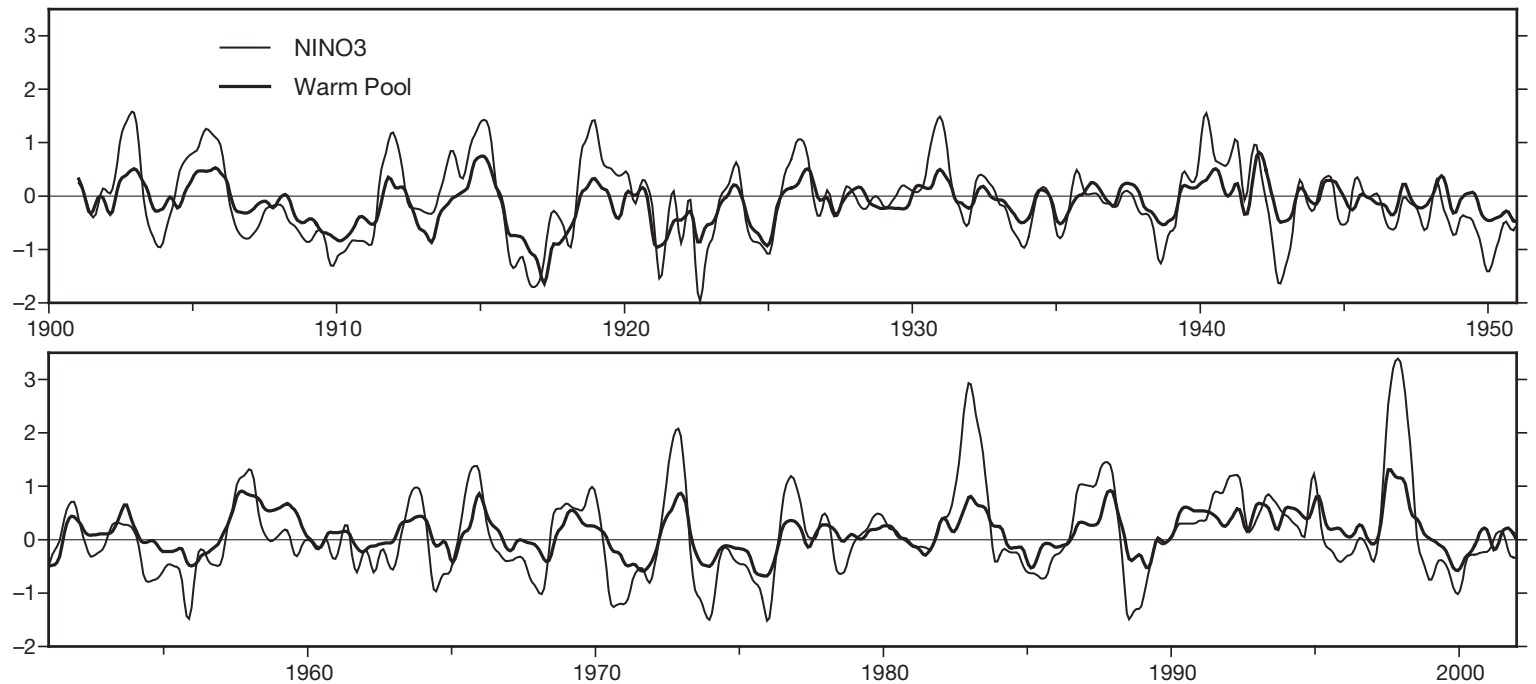

b) Cumulative sums: monthly sea surface temperature anomaly, ${ }^{\circ} \mathrm{C}$

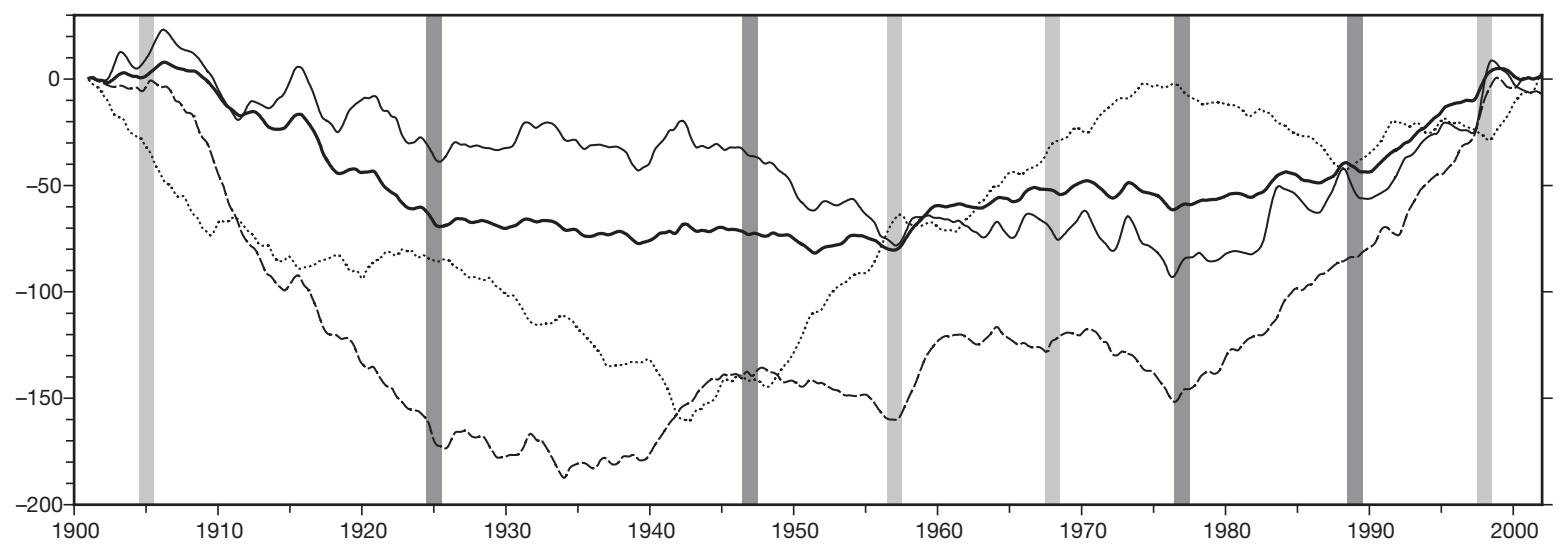

c) 10-year variance of monthly sea surface temperature anomalies, ${ }^{\circ} \mathrm{C}^{2}$ (ETP only)

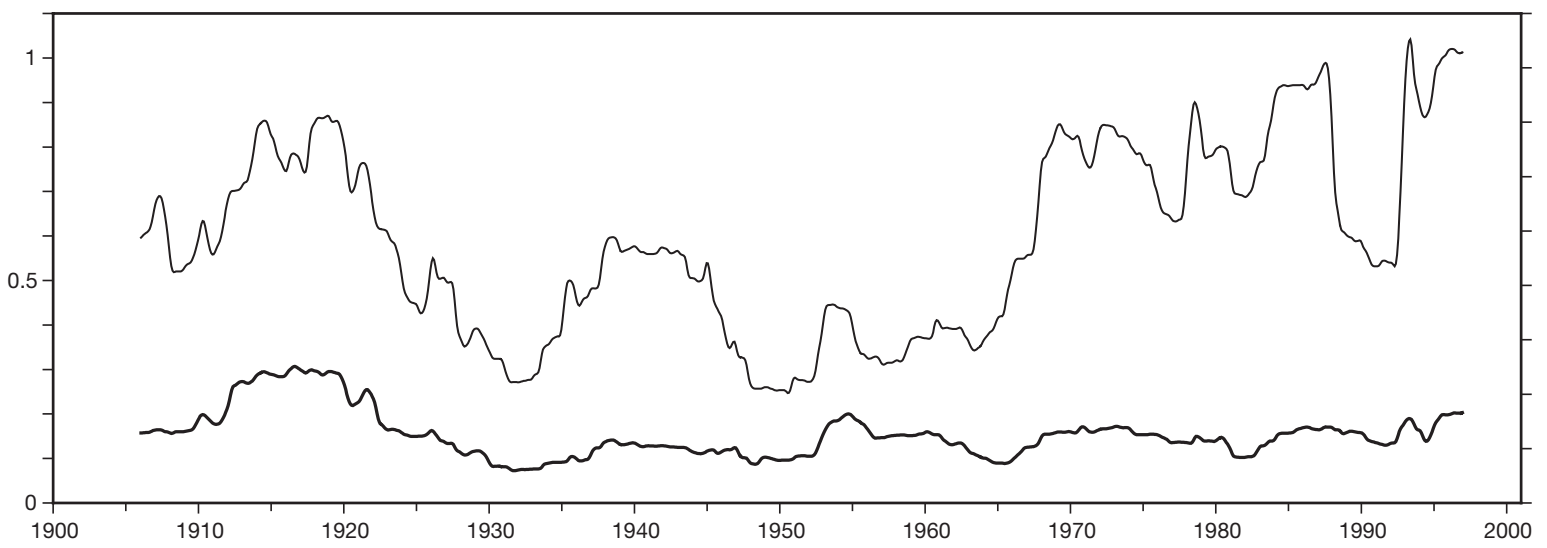

Fig. 6. SST monthly anomaly time series (a, only ETP series shown for clarity), cumulative sums (b) and 10 yr running variance (c, ETP series only), for 1901 to 2001 in ETP and North Pacific regions (see Fig. 5). Shaded bars mark climate shifts from published analyses of ocean and air temperature and atmospheric pressure data (light shading $=$ limited evidence): 1906-072, 1924-252-5,8, $1946-47^{2-5,8,9}, 1956-57^{2}, 1967-68^{2}, 1976-77^{1-9}, 1988-89^{1,5-8}, 1998-99 .{ }^{1}$ Trenberth \& Hurrell $(1994),{ }^{2}$ Ware $(1995),{ }^{3}$ Mantua et al. (1997), ${ }^{4}$ Minobe (1997), ${ }^{5}$ Beamish et al. (1999), ${ }^{6}$ Watanabe \& Nitta (1999), ${ }^{7}$ Hare \& Mantua (2000), ${ }^{8}$ McFarlane et al. (2000), ${ }^{9}$ Biondi et al. (2001). Area means from the UK Meteorological Office Global Sea-ice SST (GISST, v. 2.3b) data (Parker et al. 1995), obtained from British Atmospheric Data Centre 
linear trends during the 1980 to 2001 period; ENSO variability predominated.

Reconstructed SST time series cover longer periods than series based only upon instrumental observations. SST monthly anomaly time series since 1901 show ENSO scale variability (Fig. 6a); climate shifts are evident when the series are viewed as cumulative sums (Fig. 6b). The 1976-77 climate shift is evident in the ETP and North Pacific, although the changes in slope are much greater in the North Pacific than in the ETP. At this time, long-term warming begins in the ETP and California Current, while cooling begins in the central North Pacific. The 1989 climate shift is apparent only in the North Pacific, although a slight change in slope for the California Current occurs in the early 1990s. Similarly, the prolonged warm period of the early 1990s in the ETP results in a slight change in slope. In general, the cumulative sums show a prevalence of warm and cool periods of 2 to 3 yr associated with ENSO events in the ETP, and longer warming and cooling trends in the North Pacific corresponding to decadal scale variability. The NINO3 series in Fig. 6a also shows an apparent change in the frequency and amplitude of ENSO variability in the mid-1970s (An \& Wang 2000). The change in ENSO amplitude is illustrated by the increased $10 \mathrm{yr}$ variance in NINO3 SST monthly anomalies after the late 1960s (Fig. 6c), for which there is no corresponding change in the ETP warm pool.

Time series of other tropical Pacific, North Pacific and global climate indices are plotted in Fig. 7. NINO3, TNI and PDO are temperature indices. SOI NPI, and NOI are atmospheric pressure indices. GAAM is a global index representing the overall 'rotation' of the Earth's atmosphere; interannual changes in GAAM result from variations in trade winds, westerlies, and jet-streams associated with ENSO and other global scale climate changes (Salstein \& Rosen 1984). All of these climate indices underwent a shift in the winter of 1976-77. The late 1980s climate shift in the North Pacific (Hare \& Mantua 2000) is not evident in any of the series in Fig. 7, but is evident in the Central North Pacific SST series (Fig. 6b). No climate shift is evident in the tropical Pacific since 1976-77, although it is possible that a 1998-99 shift is as yet unresolved with only 3 to $4 \mathrm{yr}$ of observations to the present time (Schwing \&
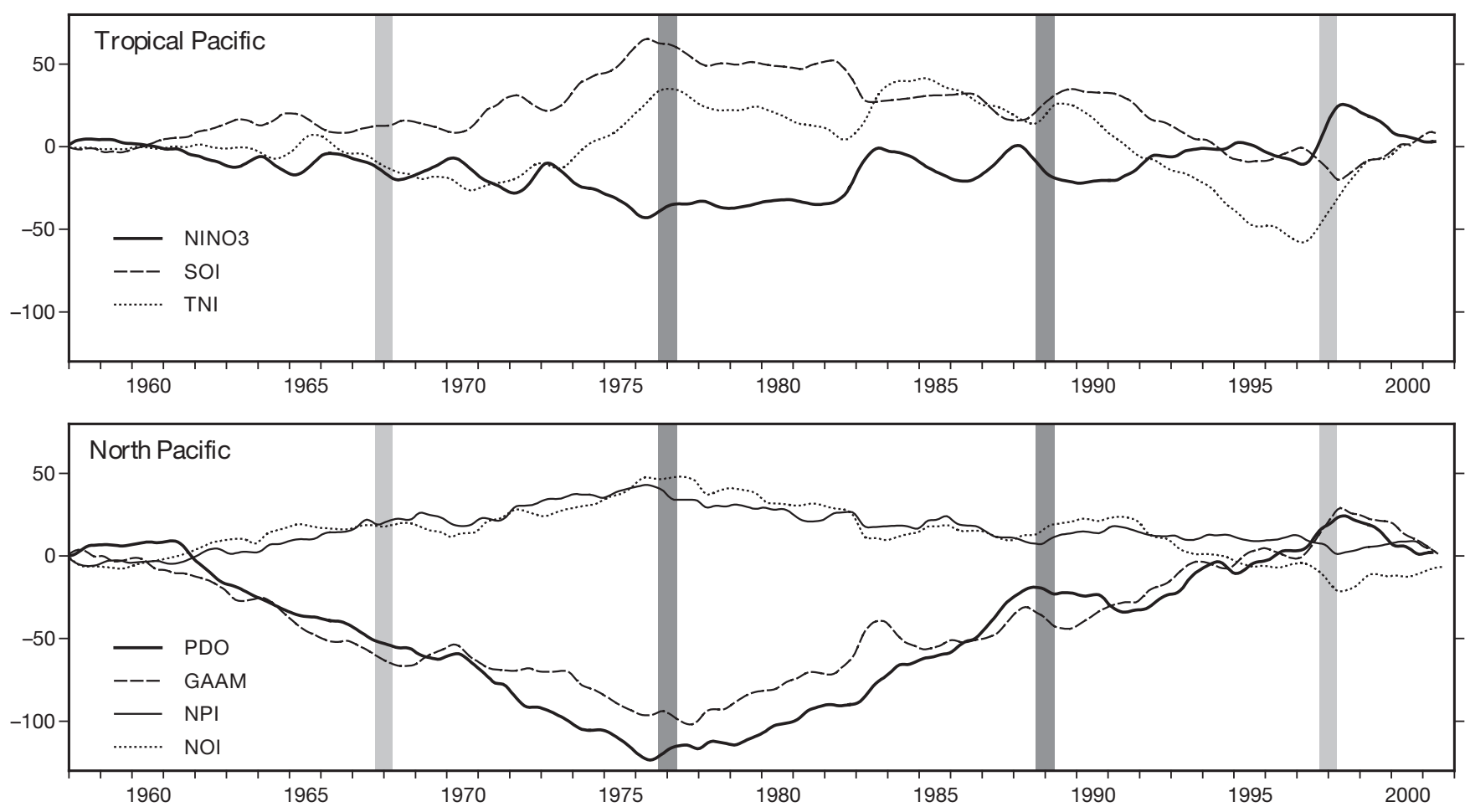

Fig. 7. Cumulative sums of monthly normalized time series of climate indices from the tropical Pacific (top) and the North Pacific (bottom). NINO3 = NINO3 SST anomaly (eastern equatorial Pacific), SOI = Southern Oscillation Index (surface pressure difference between Tahiti and Darwin), TNI = Trans-Niño Index (gradient of SST across eastern and central equatorial Pacific, Trenberth \& Stepaniak 2001), PDO = Pacific Decadal Oscillation (leading principal component of North Pacific monthly SST variability; Mantua et al. 1997), GAAM = Global Atmospheric Angular Momentum (Weickmann et al. 2000), NPI = North Pacific Index $\left(\mathrm{SLP} 30^{\circ}\right.$ to $65^{\circ} \mathrm{N}, 160^{\circ} \mathrm{E}$ to $140^{\circ} \mathrm{W}$, Trenberth \& Hurrell 1994), NOI = Extratropical Northern Oscillation Index (surface pressure difference between North Pacific High and Darwin, Schwing et al. 2002). Shaded bars mark published climate shifts from Fig. 6 
Table 1. Linear trends in monthly anomalies from 1980 to 2001 of sea surface temperature and thermocline depth in ETP and North Pacific regions (Fig. 4). Data from NCEP (NOAA/ NWS/National Center for Environmental Prediction) monthly hindcast fields (Behringer et al. 1998). ${ }^{*} \mathrm{p}<0.05,{ }^{* * *} \mathrm{p}<0.001$; NS: not significant

\begin{tabular}{|lcc|}
\hline & $\begin{array}{c}\text { SST } \\
\left({ }^{\circ} \mathrm{yr}^{-1}\right)\end{array}$ & $\begin{array}{c}\text { Thermocline depth } \\
\left(\mathrm{m} \mathrm{yr}^{-1}\right)\end{array}$ \\
\hline NINO3 & $-0.013 \mathrm{NS}$ & $-0.36^{* 2}$ \\
ETP Warm Pool & $+0.003 \mathrm{NS}$ & $-0.28^{* * * 3}$ \\
California Current & $+0.009 \mathrm{NS}$ & $+0.15 \mathrm{NS}$ \\
Central North Pacific & $+0.047^{* * * 1}$ & $+0.13 \mathrm{NS}$ \\
1 +0.009 NS for 1980 to 1997 & \\
$2-0.041$ NS for 1980 to $1998,+0.647^{*}$ for 1984 to 1998 \\
${ }^{3}-0.088$ NS for 1980 to $1998,+0.486^{* * *}$ for 1984 to 1998 \\
\hline
\end{tabular}

Moore 2000). As El Niño returns in 2002, ENSO continues to dominate interannual variability in the ETP.

A recent paper (McPhaden \& Zhang 2002) presented evidence that sea surface warming in the equatorial Pacific since the 1970s is associated with a decrease in equatorial upwelling that is part of the meridional overturning circulation forced by easterly trade winds. The authors suggest that the reduction in upwelling should also affect biological production in the region. Time series of zonal trade wind strength since 1948 show weakening during the 1970s (Fig. 8), with a greater change in the central equatorial Pacific than in the eastern equatorial Pacific (winds are more easterly in the central and more southerly in the eastern equatorial Pacific, with mean zonal components of -5.29 and $-2.66 \mathrm{~m} \mathrm{~s}^{-1}$ respectively). Long time series of phytoplankton biomass or productivity in the equatorial Pacific are not available or have not been published. Available satellite and shipboard data indicate that phytoplankton biomass has not changed in the central equatorial Pacific, has decreased slightly in the eastern equatorial Pacific since the end of the 1980s and has actually increased in the warm pool of the ETP (Gregg \& Conkright 2002, Fig. 8).

\section{CONCLUSION}

The studies reviewed above show that oceanographic variability occurs in the ETP and North Pacific at both ENSO ( 2 to $7 \mathrm{yr}$ ) and decadal (10 to $30 \mathrm{yr}$ ) scales. ENSO scale variability predominates in the ETP, and appears in the North Pacific with some delay and attenuation. Decadal scale variability predominates in the North Pacific although some decadal scale changes are evident in the ETP. This review has been limited to a description of such variability and has not considered theory or mechanisms, because it was moti- vated by a need to examine possible effects of environmental change on dolphin stocks in the ETP. The eastern equatorial Pacific (NINO3, Fig. 4) corresponds to the southern portion of the area in which the US National Marine Fisheries Service and the Interamerican Tropical Tuna Commission monitor dolphin abundance and manage a yellowfin tuna fishery. The ETP warm pool area covers the distribution of 2 depleted dolphin stocks: northeastern offshore spotted dolphins and eastern spinner dolphins.

ENSO variability has been shown to affect fish, birds, pinnipeds and cetaceans. Almost all observations of such environmental effects have been on coastal or island populations. While it is true that ENSO effects are more extreme in highly productive coastal environments, other factors may be important. Perhaps such populations are less adaptable or opportunistic. Certainly, these populations are more readily accessible for long-term study. El Niño events often cause changes in distribution of species as the distribution of preferred water masses and prey changes. Population effects are observed on local breeding grounds, but recovery usually occurs rapidly when the El Niño event is over. Effects of El Niño on distribution of dolphins in the ETP were recognized by Gerrodette et al. (1998) in planning recent dolphin abundance surveys. They compared maps of encounter rates from tuna vessels (1975 to 1996) and research vessels (1982 to 1993) for El Niño and non-El Niño years. Both eastern spinner and offshore spotted dolphins showed slight expansions of range during El Niño years, but there was no indication of movement out of the survey area. Population effects of ENSO on ETP dolphins have not been detected. The long life spans, iteroparity and low reproductive rates of these K-selected species, and their generalized feeding habits, probably reduce dolphin population responses to moderate changes on seasonal and ENSO time scales (Musick 1999).

There is no evidence of environmental change, in the sense of a decadal scale climate shift, in the ETP since the 1970s. Although the 1976-77 climate shift was not a unique change in the North Pacific environment, it was of exceptional magnitude. Stephens et al. (2001) showed that the mid-1970s shift in Pacific upper ocean temperature was a basin-wide warming that continued through 1998 with no signs of returning to a cooler phase. Since the end of the 1997-98 El Niño, however, there has been conjecture about a winter 1998-99 regime shift (Hare \& Mantua 2000, Schwing \& Moore 2000, Peterson \& Mackas 2001, Minobe 2002). As of May 2000, the consensus of scientists working in the California Current was that the system was in a third straight La Niña year and that data did 'not yet support the idea of a climate regime shift' (Durazo et al. 2001). The question of whether recent changes in 
the North Pacific are a climate regime shift is not yet decided and continues to be discussed at scientific meetings.

The magnitude of a climate signal cannot be assumed to affect a biological response in a linear fash- ion (Hunt et al. 2002). The SST time series in Fig. 6 and other environmental time series in Fig. 7 indicate that the 1976-77 climate shift in the eastern equatorial Pacific was less than half the magnitude it was in the North Pacific. The change was even smaller in the

a) Trade Wind Index (zonal wind speed monthly anomaly, $\mathrm{m} \mathrm{s}^{-1}$ )

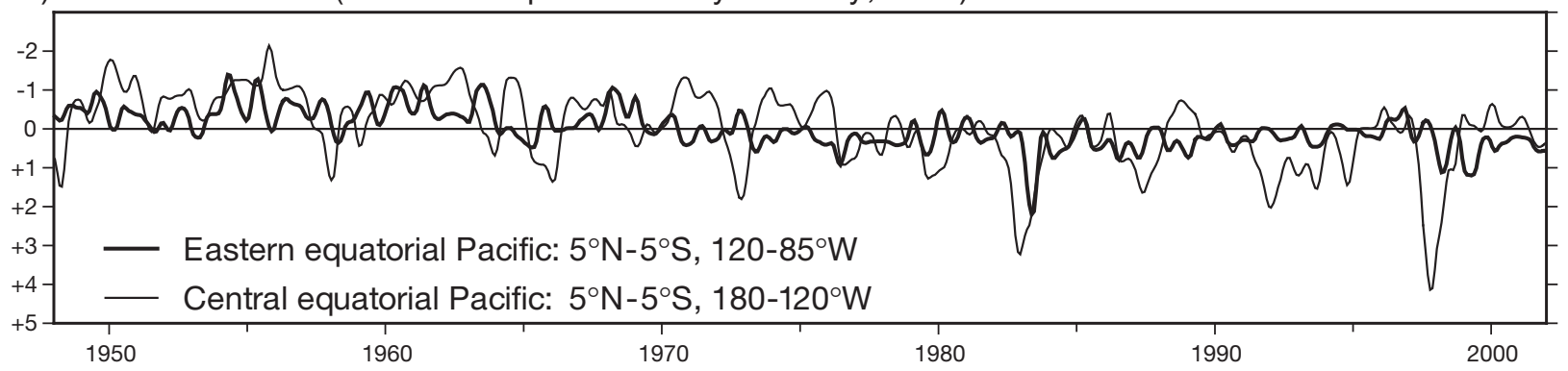

b) Cumulative sum: Trade Wind Index

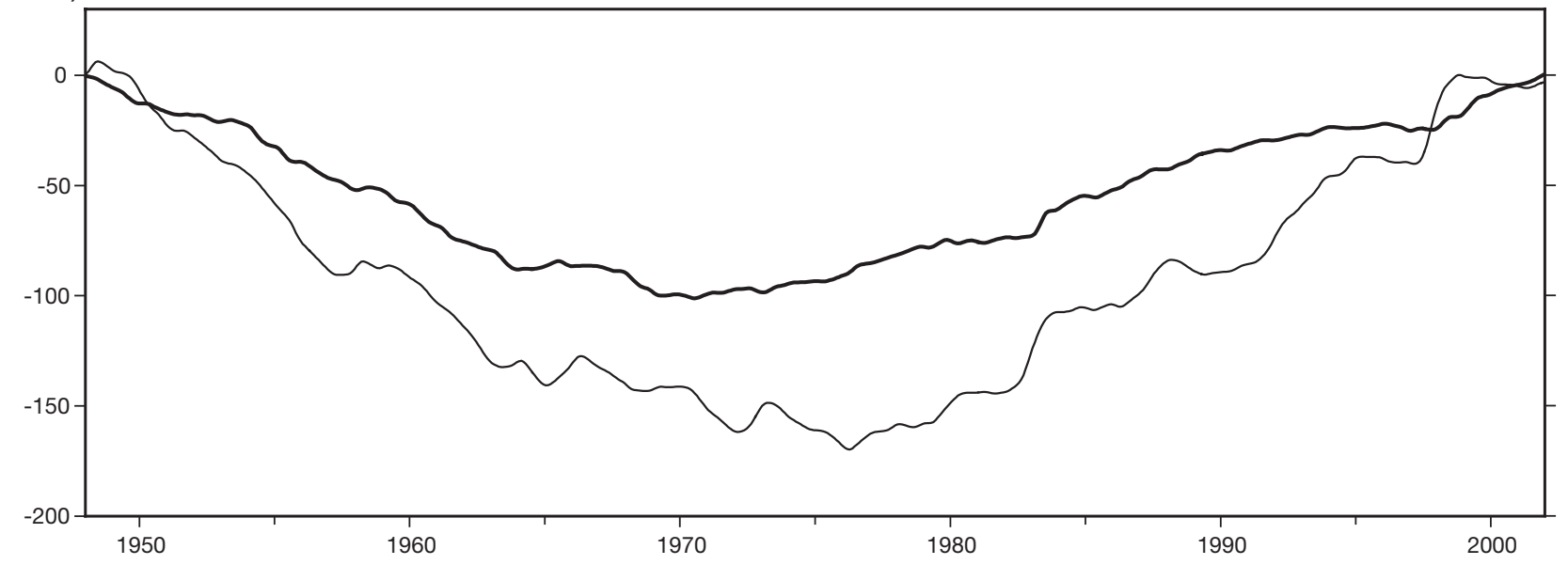

c) Surface chlorophyll, $\mathrm{mg} \mathrm{m}^{-3}$

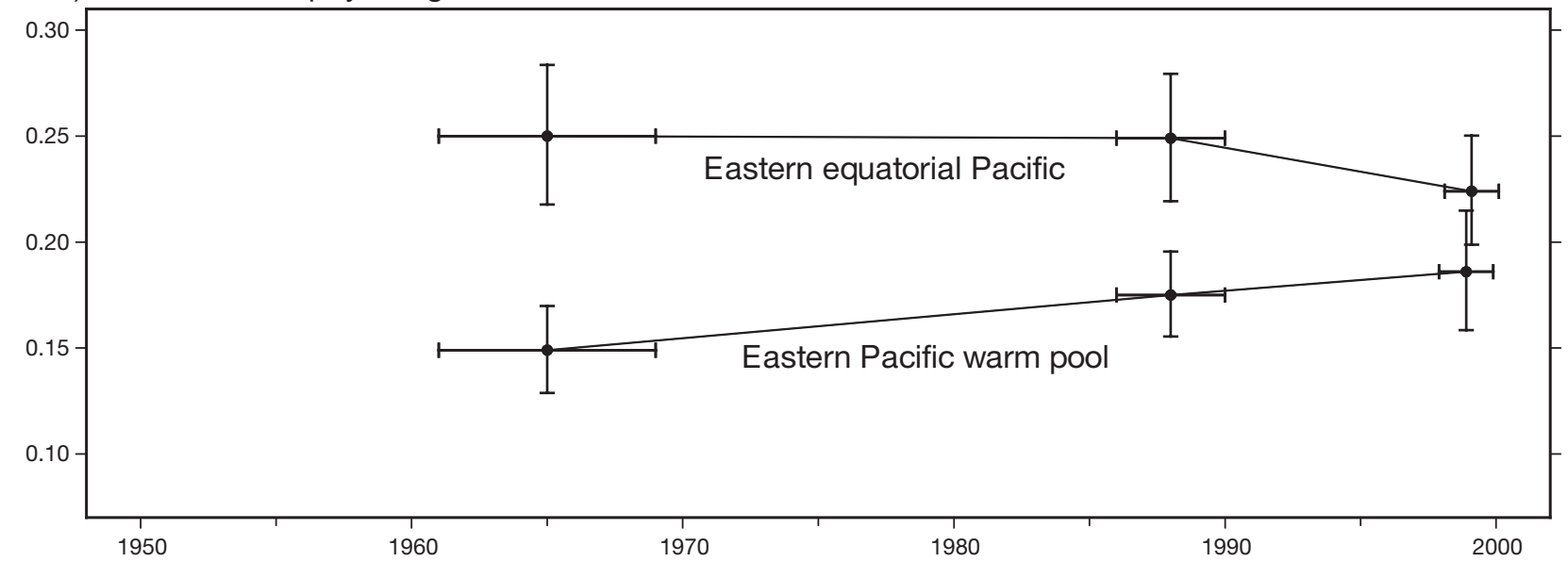

Fig. 8. Equatorial Pacific trade wind indices (A) and cumulative sums (B). Monthly areal means calculated from NCEP Reanalysis data from NOAA-CIRES Climate Diagnostics Center web site (www.cdc.noaa.gov). Mean surface chlorophyll concentrations (C) east of $120^{\circ} \mathrm{W}$ from August to November from gridded values of log-transformed observations for 1960 to 1969 (NODC World Ocean Database 2001, Conkright et al. 2002) and for 1986 to 1990 and 1998 to 2000 (Fiedler \& Philbrick 2002). Vertical error bars represent $95 \%$ confidence limits estimated from the SD of gridded values, assuming that autocorrelation and smoothing reduces the effective degrees of freedom by a factor of 10 
warm pool area of the ETP. It is possible that population and ecosystem changes were induced in the ETP, as they were in the California Current and Gulf of Alaska; however, there is no observational evidence of such changes. The long-term change that occurred in the ETP in the late 1970s was less than typical interannual changes associated with ENSO variability. However, the persistence of such a low amplitude change may be important to organisms and populations adapted to intense ENSO scale variability.

Studies of environmental variability and change in recent years have often been carried out to resolve effects of human-induced factors such as overfishing or global warming. Fisheries scientists have recognized since the early 1990s that environmental variability is at least as important as fishing mortality or other anthropogenic factors in forcing variability of fish stocks (Southward et al. 1988, Sharp \& McLain 1993). However, the UN Intergovernmental Panel on Climate Change has consistently emphasized that potential impacts of climate variability or climate change are likely to exacerbate, rather than replace, existing human stresses on fisheries (Everett et al. 1996, Burkett et al. 2001). In the case of dolphins and other marine mammals, life history traits that may have evolved in part as an adaptive response to cyclic perturbations such as ENSO (long life spans, slow growth rates, late maturity and relatively few offspring), also render them vulnerable to excessive human-induced or other population reductions (Musick 1999, Fair \& Becker 2000). Interaction between natural variability and human intervention must be considered in management decisions.

Acknowledgements. I thank Lisa Ballance, John Dower, Ken Drinkwater, George Hunt, Nate Mantua, Alberto Mestas, Art Miller, Hazel Oxenford, Steve Reilly, Frank Schwing, Paul Thompson and 3 anonymous reviewers for reading earlier drafts of this paper and offering valuable suggestions.

\section{LITERATURE CITED}

Ainley DG, Carter HR, Anderson DW, Briggs KT and 9 others (1988) Effects of the 1982-83 El Niño-Southern Oscillation on Pacific Ocean bird populations. In: Onelet H (ed) Proc XIX Int Ornithol Congr. National Museum of Natural Sciences, Ottawa, p 1747-1757

Ainley DG, Sydeman WJ, Norton J (1995) Upper trophic level predators indicate interannual negative and positive anomalies in the California Current food web. Mar Ecol Prog Ser 118:69-79

Ainley DG, Spear LB, Allen SG (1996) Variation in the diet of Cassin's auklet reveals spatial, seasonal, and decadal occurrence patterns of euphausiids off California, USA. Mar Ecol Prog Ser 137:1-10

An SI, Wang B (2000) Interdecadal change of the structure of the ENSO mode and its impact on the ENSO frequency. J Clim 13:2044-2055
Anderson DJ (1989) Differential responses of boobies and other seabirds in the Galápagos to the 1986-87 El NiñoSouthern Oscillation event. Mar Ecol Prog Ser 52:209-216

Anderson RY (1992) Long-term changes in the frequency of occurrence of El Niño events. In: Diaz HF, Markgraf V (eds) El Niño: historical and paleoclimatic aspects of the southern oscillation. Cambridge University Press, Cambridge, p 193-200

Anderson PJ, Piatt JF (1999) Community reorganization in the Gulf of Alaska following ocean climate regime shift. Mar Ecol Prog Ser 189:117-123

Bakun A (1990) Global climate change and intensification of coastal ocean upwelling. Science 247:198-201

Barber RT, Chavez FP (1983) Biological consequences of El Niño. Science 222:1203-1210

Barber RT, Chavez FP (1986) Ocean variability in relation to living resources during the 1982-83 El Niño. Nature 319: 279-285

Barber RT, Chavez FP, Kogelschatz JE (1985) Biological effects of El Niño. Bol ERFEN 14:3-29

Beamish RJ, Noakes DJ, McFarlane GA, Klyashtorin L, Ivanov VV, Kurashov V (1999) The regime concept and natural trends in the production of Pacific salmon. Can J Fish Aquat Sci 56:516-526

Behringer DW, Ji M, Leetmaa A (1998) An improved coupled model for ENSO prediction and implications for ocean initialization. Part I: the ocean data assimilation system. Mon Weather Rev 126:1013-1021

Biondi F, Gershunov A, Cayan DR (2001) North Pacific decadal climate variability since 1661 . J Climate 14:5-10

Brodeur RD, Ware DM (1992) Long-term variability in zooplankton biomass in the subarctic Pacific Ocean. Fish Oceanogr 1:32-38

Brodeur RD, Frost BW, Hare SR, Francis RC, Ingraham WJ (1996) Interannual variations in zooplankton biomass in the Gulf of Alaska, and covariation with California Current zooplankton biomass. CalCOFI Rep 37:80-99

Burkett V, Codignotto JO, Forbes DL, Mimura N, Beamish RJ, Ittekkot V (2001) Coastal zones and marine ecosystems. In: McCarthy JJ, Canziani OF, Leary NA, Dokken DJ, White KS (eds) Climate change 2001: impacts, adaptation, and vulnerability. Contribution of Working Group II to the Third Assessment Report of the Intergovernmental Panel on Climate Change. Cambridge University Press, Cambridge, p 347-379

Carrasco S, Lozano O (1989) Seasonal and long-term variations of zooplankton volumes in the Peruvian Sea, 1964-1987. In: Pauly D, Muck P, Mendo J, Tsukayama I (eds) The Peruvian upwelling system: dynamics and interactions. ICLARM Conf Proc, 18:82-85

Chao Y, Ghil M, McWilliams JC (2000) Pacific interdecadal variability in this century's sea surface temperatures. Geophys Res Lett 27:2261-2264

Chavez FP, Strutton PG, Friederich GE, Feely RA, Feldman GC, Foley DG, McPhaden MJ (1999) Biological and chemical response of the equatorial Pacific Ocean to the 199798 El Niño. Science 286:2126-2131

Clarke AJ, Lebedev A (1996) Long-term changes in the equatorial Pacific trade winds. J Clim 9:1020-1029

Conkright ME, Antonov JI, Baranova O, Boyer TP and 8 others (2002) World Ocean Database 2001, Vol 1: introduction. NOAA Atlas NESDIS 42. US Government Printing Office, Washington, DC

Crawford RJM, Jahncke J (1999) Comparison of trends in abundance of guano-producing seabirds in Peru and southern Africa. S Afr J Mar Sci 21:145-156

Dandonneau Y (1986) Monitoring the sea surface chlorophyll 
concentration in the tropical Pacific: consequences of the 1982-83 El Niño. Fish Bull 84:687-695

Dee Boersma P (1998) Population trends of the Galápagos penguin: impacts of El Niño and La Niña. Condor 100: $245-253$

Delcroix T (1993) Seasonal and interannual variability of sea surface temperatures in the tropical Pacific, 1969-1991. Deep-Sea Res I 40:2217-2228

DeLong RL, Melin SR (2000) Thirty years of pinniped research at San Miguel Island. In: Browne DR, Mitchell KL, Chaney HW (eds) 5th Calif Islands Symp, US Department of the Interior, Minerals Management Service, p 401-406

Dessier A, Donguy JR (1987) Response to El Niño signals of the epiplanktonic copepod populations in the eastern tropical Pacific. J Geophys Res C 92:14 393-14 403

Diaz HF, Markgraf V (1992) El Niño: historical and paleoclimatic aspects of the Southern Oscillation. Cambridge University Press, Cambridge

Diaz HF, Markgraf V (2000) El Niño and the Southern Oscillation: multiscale variability and global and regional impacts. Cambridge University Press, Cambridge

Downton MW, Miller KA (1998) Relationships between Alaska salmon catch and North Pacific climate on interannual and interdecadal time scales. Can J Fish Aquat Sci 55:2255-2265

Durazo R, Baumgartner TR, Bograd SJ, Collins CA and 11 others (2001) The state of the California Current, 2000-2001: a third straight La Niña year. CalCOFI Rep 42:29-60

Ebbesmeyer CC, Cayan DR, McLain DR, Nichols FH, Peterson DH, Redmond KT (1991) 1976 step in the Pacific climate: forty environmental changes between 1968-1975 and 1977-1984. In: Betancourt JL, Tharp VL (eds) Proc 7th Annu Pacif Clim (PACLIM) Workshop, April 1990. Calif Dep Water Resources Interagency Ecol Stud Program Tech Rep 26:115-126

Enfield DB (1992) Historical and prehistorical overview of El Niño/Southern Oscillation. In: Diaz HF, Markgraf V (eds) El Niño: historical and paleoclimatic aspects of the Southern Oscillation. Cambridge University Press, Cambridge, p 95-117

Enfield DB, Mestas-Nuñez AM (2000) Global modes of ENSO and non-ENSO sea surface temperature variability and their associations with climate. In: Diaz HF, Markgraf V (eds) El Niño and the Southern Oscillation: multiscale variability and global and regional impacts. Cambridge University Press, Cambridge, p 89-112

Everett JE, Krovnin A, Lluch-Belda D, Okemwa E, Regier HA, Troadec JP (1996) Fisheries. In: Watson RT, Zinyowera MC, Moss RH (eds) Climate change 1995: impacts, adaptations and mitigations of climate change: scientific-technical analyses. Contribution of Working Group II to the 2nd Assessment Report of the Intergovernmental Panel on Climate Change. Cambridge University Press, Cambridge, p 511-537

Fair PA, Becker PR (2000) Review of stress in marine mammals. J Aquat Ecosyst Stress Recovery 7:335-354

Fedorov AV, Philander SG (2000) Is El Niño changing? Science 288:1997-2002

Fiedler PC, Philbrick V (2002) Environmental change in the eastern tropical Pacific Ocean: observations in 1986-1990 and 1998-2000. NMFS Southwest Fisheries Science Center Admin Rep LJ-02-15

Fiedler PC, Chavez FP, Behringer DW, Reilly SB (1992) Physical and biological effects of Los Niños in the eastern tropical Pacific, 1986-1989. Deep-Sea Res I 39:199-219

Francis RC, Hare SR, Hollowed AB, Wooster WS (1998)
Effects of interdecadal climate variability on the oceanic ecosystems of the NE Pacific. Fish Oceanogr 7:1-21

Gagan MK, Ayliffe LK, Beck JW, Cole JE, Druffel ERM, Dunbar RB, Schrag DP (2000) New views of tropical paleoclimates from corals. Quat Sci Rev 19:45-64

Gardner SC, Chávez-Rosales S (2000) Changes in the relative abundance and distribution of gray whales (Eschrichtius robustus) in Magdalena Bay, Mexico during an El Niño event. Mar Mamm Sci 16:728-738

Gedalof Z, Smith DJ (2001) Interdecadal climate variability and regime-scale shifts in Pacific North America. Geophys Res Lett 28:1515-1518

Gerrodette T, Olson P, Kinzey D, Anganuzzi A, Fiedler P, Holland R (1998) Report of the survey design meeting for estimating abundance of eastern tropical Pacific dolphins, 1998-2000: December 17-18, 1997. NMFS Southwest Fisheries Science Center Admin Rep LJ-98-03

Ghil M, Vautard R (1991) Interdecadal oscillations and the warming trend in global temperature time series. Nature 350:324-327

Giese BS, Carton JA (1999) Interannual and decadal variability in the tropical and midlatitude Pacific Ocean. J Clim 12:3402-3418

Glynn PW, De Weerdt WH (1991) Elimination of two reefbuilding hydrocorals following the 1982-83 El Niño warming event. Science 253:69-71

Goddard L, Graham NE (1997) El Niño in the 1990s. J Geophys Res C 102:10 423-10 436

Gómez-Gutiérrez J, Palomares-García R, Gendron D (1995) Community structure of the euphausiid populations along the west coast of Baja California, Mexico, during the weak ENSO 1986-1987. Mar Ecol Prog Ser 120:41-51

González HE, Sobarzo M, Figueroa D, Nöthig EM (2000) Composition, biomass and potential grazing impact of the crustacean and pelagic tunicates in the northern Humboldt Current area off Chile: differences between El Niño and non-El Niño years. Mar Ecol Prog Ser 195:201-220

Gregg WW, Conkright ME (2002) Decadal changes in global ocean chlorophyll. Geophys Res Lett 29(15):10.1029/2002 GLO14689

Hare SR, Mantua NJ (2000) Empirical evidence for North Pacific regime shifts in 1977 and 1989. Prog Oceanogr 47: 103-145

Hollowed AB, Hare SR, Wooster WS (2001) Pacific Basin climate variability and patterns of Northeast Pacific marine fish production. Prog Oceanogr 49:257-282

Hunt GL, Stabeno P, Walters G, Sinclair E, Brodeur RD, Napp JM, Bond NA (2002) Climate change and control of the southeastern Bering Sea ecosystem. Deep-Sea Res II 49: (in press)

Huyer A, Smith RL, Paluszkiewicz T (1987) Coastal upwelling off Peru during normal and El Niño times, 1981-1984. J Geophys Res C 92:14 297-14 307

Karl DM, Bidigare RR, Letelier RM (2001) Long-term changes in plankton community structure and productivity in the North Pacific Subtropical Gyre: the domain shift hypothesis. Deep-Sea Res II 48:1449-1470

Larkin NK, Harrison DE (2001) Tropical Pacific ENSO cold events, 1946-95: SST, SLP, and surface wind composite anomalies. J Clim 14:3904-3931

Latif M, Kleeman R, Eckert C (1997) Greenhouse warming, decadal variability, or El Niño? An attempt to understand the anomalous 1990s. J Clim 10:2221-2239

Lavaniegos BE, Gómez-Gutiérrez J, Lara-Lara JR, Hernández-Vázquez S (1998) Long-term changes in zooplankton volumes in the California Current System - the Baja California region. Mar Ecol Prog Ser 169:55-64 
Lehodey P, Bertignac M, Hampton J, Lewis A, Picaut J (1997) El Niño Southern Oscillation and tuna in the western Pacific. Nature 389:715-718

Lenarz WH, Ventresca DA, Graham WM, Schwing FB, Chavez F (1995) Explorations of El Niño events and associated biological population dynamics off central California. CalCOFI Rep 36:106-119

Linsley BK, Ren L, Dunbar RB, Howe SS (2000) El Niño Southern Oscillation (ENSO) and decadal-scale climate variability at $10^{\circ} \mathrm{N}$ in the eastern Pacific from 1893 to 1994: a coral-based reconstruction from Clipperton Atoll. Paleoceanography 15:322-335

Lluch-Belda D, Crawford RJM, Kawasaki T, MacCall AD, Parrish RH, Schwartzlose RA, Smith PE (1989) World-wide fluctuations of sardine and anchovy stocks: the regime problem. S Afr J Mar Sci 8:195-205

Lluch-Belda D, Lluch-Cota DB, Hernández-Vázquez S, Salinas-Zavala CA (1992) Sardine population expansion in eastern boundary systems of the Pacific Ocean as related to sea surface temperature. S Afr J Mar Sci 12:147-155

Lluch-Belda D, Laurs RM, Lluch-Cota DB, Lluch-Cota SE (2001) Long-term trends of interannual variability in the California Current system. CalCOFI Rep 42:129-144

Lluch-Cota DB, Hernández-Vázquez S, Lluch-Cota SE (1997) Empirical investigation on the relationship between climate and small pelagic global regimes and El Niño-Southern Oscillation (ENSO). FAO Fish Circ No. 934

Majluf P, Reyes JC (1989) The marine mammals of Peru: a review. In: Pauly D, Muck P, Mendo J, Tsukayama I (eds) The Peruvian upwelling system: dynamics and interactions, ICLARM Conf Proc 18, p 344-363

Manly BFJ, Mackenzie D (2000) A cumulative sum type of method for environmental monitoring. Environmetrics 11: 151-166

Mann ME, Gille E, Bradley RS, Hughes MK, Overpeck J, Keimig FT, Gross W (2000) Global temperature patterns in past centuries: an interactive presentation. Earth Interactions 4(4):1-29

Mantua NJ, Hare SR, Zhang Y, Wallace JM, Francis RC (1997) A Pacific interdecadal climate oscillation with impacts on salmon production. Bull Am Meteorol Soc 78: 1069-1079

Manzanilla SR (1989) The 1982-1983 El Niño event recorded in dentinal growth layers in teeth of Peruvian dusky dolphins (Lagenorhynchus obscurus). Can J Zool 67:2120-2125

McFarlane GA, King JR, Beamish RJ (2000) Have there been recent changes in climate? Ask the fish. Prog Oceanogr 47:147-169

McGowan JA, Chelton DB, Conversi A (1996) Plankton patterns, climate, and change in the California Current. CalCOFI Rep 37:45-68

McGowan JA, Cayan DR, Dorman LM (1998) Climate-ocean variability and ecosystem response in the Northeast Pacific. Science 281:210-217

McPhaden MJ, Zhang D (2002) Slowdown of the meridional overturning circulation in the upper Pacific Ocean. Nature 415:603-608

Mestas-Nuñez AM, Enfield DB (2001) Eastern equatorial Pacific SST variability: ENSO and non-ENSO components and their climatic associations. J Clim 14:391-402

Miller AJ, Schneider N (2000) Interdecadal climate regime dynamics in the North Pacific Ocean: theories, observations and ecosystem impacts. Prog Oceanogr 47:355-379

Miller AJ, Cayan DR, Barnett TP, Graham NE, Oberhuber JM (1994) The 1976-77 climate shift of the Pacific Ocean. Oceanography 7(1):21-26

Minobe S (1997) A 50-70 year climatic oscillation over the
North Pacific and North America. Geophys Res Lett 24 683-686

Minobe S (1999) Resonance in bidecadal and pentadecadal climate oscillations over the North Pacific: role in climatic regime shifts. Geophys Res Lett 26:855-858

Minobe S (2002) Interannual to interdecadal changes in the Bering Sea and concurrent 1998/99 changes over the North Pacific. Prog Oceanogr (in press)

Moron V, Vautard R, Ghil M (1998) Trends, interdecadal and interannual oscillations in global sea-surface temperatures. Clim Dyn 14:545-569

Muck P (1989) Major trends in the pelagic ecosystem off peru and their implications for management. In: Pauly D, Muck P, Mendo J, Tsukayama I (eds) The Peruvian upwelling system: dynamics and interactions. ICLARM Conf Proc 18: 386-403

Musick JA (1999) Life in the slow lane: ecology and conservation of long-lived marine animals. Am Fish Soc Symp 23: 265

Mysak LA (1986) El Niño, interannual variability and fisheries in the northeast Pacific Ocean. Can J Fish Aquat Sci 43: 464-497

Neelin JD, Battisti DS, Hirst AC, Jin FF, Wakata Y, Yamagata T, Zebiak SE (1998) ENSO theory. J Geophys Res C 103: $14261-14290$

Parker DE, Folland CK, Jackson M (1995) Marine surface temperature: observed variations and data requirements. Clim Change 31:559-600

Peterson WT, Mackas DL (2001) Shifts in zooplankton abundance and species composition off central Oregon and southwestern British Columbia. PICES Press 9(2):28-31

Philander SGH (1990) El Niño, La Niña and the Southern Oscillation. Academic Press, New York, p 289

Philander SGH (1999) A review of tropical ocean-atmosphere interactions. Tellus 51:71-90

Pierce DW, Barnett TP, Latif M (2000) Connections between the Pacific Ocean tropics and midlatitudes on decadal timescales. J Clim 13:1173-1194

Polovina JJ (1996) Decadal variation in the trans-Pacific migration of northern bluefin tuna (Thunnus thynnus) coherent with climate-induced change in prey abundance. Fish Oceanogr 5(2):114-119

Polovina JJ, Mitchum GT, Graham NE, Craig MP, DeMartini EE, Flint EN (1994) Physical and biological consequences of a climate event in the central North Pacific. Fish Oceanogr 3(1):15-21

Polovina JJ, Mitchum GT, Evans GT (1995) Decadal and basin-scale variation in mixed layer depth and the impact on biological production in the Central and North Pacific, 1960-88. Deep-Sea Res I 42:1701-1716

Quinn WH, Neal VT, Antunez de Mayolo SE (1987) El Niño occurrences over the past four and a half centuries. J Geophys Res C 92:14 449-14 461

Rajagopalan B, Lall U, Cane MA (1997) Anomalous ENSO occurrences: an alternate view. J Clim 10:2351-2357

Ramirez P (1986) Distribucion y alimentacion de la ballena Bryde durante al fenomeno 'El Niño' 1982-1983. Bol ERFEN 17:20-27 (English abstract)

Reynolds RW, Smith TM (1994) Improved global sea surface temperature analyses. J Clim 7:929-948

Ribic CA, Ainley DG, Spear LB (1992) Effects of El Niño and La Niña on seabird assemblages in the equatorial Pacific. Mar Ecol Prog Ser 80:109-124

Rodbell DT, Seltzer GO, Anderson DM, Abbott MB, Enfield DB, Newman JH (1999) An 15 000-year record of El Niñodriven alluviation in southwestern Ecuador. Science 283: $516-520$ 
Roemmich D, McGowan J (1995) Climatic warming and the decline of zooplankton in the California Current. Science 267:1324-1326

Salstein DA, Rosen RD (1984) El Niño and the Earth's rotation. Oceanus 27(2):52-57

Sandweiss DH, Maasch KA, Burger RL, Richardson JBI, Rollins HB, Clement A (2001) Variation in Holocene El Niño frequencies: climate records and cultural consequences in ancient Peru. Geology 29:603-606

Schreiber RW, Schreiber EA (1984) Central Pacific seabirds and the El Niño Southern Oscillation: 1982 to 1983 perspectives. Science 225:713-716

Schwartzlose RA, Alheit J, Bakun A, Baumgartner TR and 17 others (1999) Worldwide large-scale fluctuations of sardine and anchovy populations. S Afr J Mar Sci 21:289-347

Schwing FB, Moore C (2000) A year without a summer for California, or a harbinger of a climate shift? EOS, Trans Am Geophys Union 81(27):301

Schwing FB, Murphree T, Green PM (2002) The Northern Oscillation Index (NOI): a new climate index for the northeast Pacific. Prog Oceanogr 53:115-139

Setoh T, Imawaki S, Ostrovskii A, Umatani SI (1999) Interdecadal variations of ENSO signals and annual cycles revealed by wavelet analysis. J Oceanogr 55:385-394

Shane SH (1995) Relationship between pilot whales and Risso's dolphins at Santa Catalina Island, California, USA. Mar Ecol Prog Ser 123:5-11

Sharp GD (1992) Fishery catch records, El Niño/Southern Oscillation, and longer-term climate change as inferred from fish remains in marine sediments. In: Diaz HF, Markgraf V (eds) El Niño: historical and paleoclimatic aspects of the Southern Oscillation, Cambridge University Press, Cambridge, p 379-417

Sharp GD, McLain DR (1993) Fisheries, El Niño-Southern Oscillation and upper-ocean temperature records: an eastern Pacific example. Oceanography 6(1):13-22

Southward AJ, Boalch GT, Mattock L (1988) Fluctuations in the herring and pilchard fisheries of Devon and Cornwall linked to change in climate since the 16th century. J Mar Biol Assoc UK 68:423-445

Stephens C, Levitus S, Antonov J, Boyer TP (2001) On the Pacific Ocean regime shift. Geophys Res Lett 28:3721-3724

Strutton PG, Chavez FP (2000) Primary productivity in the equatorial Pacific during the 1997-1998 El Niño. J Geophys Res 105:26 089-26101

Sydeman WJ, Allen SJ (1999) Pinniped population dynamics in central California: correlations with sea surface temperature and upwelling indices. Mar Mamm Sci 15:446-461

Sydeman WJ, Hester MM, Thayer JA, Gress F, Martin P, Buffa J (2001) Climate change, reproductive performance and diet composition of marine birds in the southern California Current system, 1969-1997. Prog Oceanogr 49: 309-329

Tomita T, Wang B, Yasunari T, Nakamura H (2001) Global patterns of decadal-scale variability observed in sea surface temperature and lower-tropospheric circulation fields. J Geophys Res C 106:26 805-26 816

Tovar H, Guillén V, Cabrera D (1987) Reproduction and population levels of Peruvian guano birds, 1980 to 1986. J Geophys Res C 92:14 445-14 448

Editorial responsibility: Kenneth Sherman (Contributing Editor), Narragansett, Rhode Island, USA
Trenberth KE, Hoar TJ (1996) The 1990-1995 El Niño-Southern Oscillation event: longest on record. Geophys Res Lett 23:57-60

Trenberth KE, Hurrell JW (1994) Decadal atmosphere-ocean variations in the Pacific. Clim Dyn 9:303-319

Trenberth KE, Stepaniak DP (2001) Indices of El Niño evolution. J Clim 14:1697-1701

Trillmich F, Limberger D (1985) Drastic effects of El Niño on Galapagos pinnipeds. Oecologia 67:19-22

Tynan CT (1999) Redistributions of cetaceans in the southeast Bering Sea relative to anomalous oceanographic conditions during the 1997 El Niño. PICES Sci Rep 10: $115-117$

Valle CA, Cruz F, Cruz JB, Merlen G, Coulter MC (1987) The impact of the 1982-1983 El Niño-Southern Oscillation on seabirds in the Galapagos Islands, Ecuador. J Geophys Res C 92:14 437-14 444

Veit RR, Pyle P, McGowan JA (1996) Ocean warming and long-term change in pelagic bird abundance within the California current system. Mar Ecol Prog Ser 139: $11-18$

Venrick EL, McGowan JA, Cayan DR, Hayward TL (1987) Climate and chlorophyll a: long-term trends in the central North Pacific Ocean. Science 238:70-72

Wallace JM, Rasmusson EM, Mitchell TP, Kousky VE, Sarachik ES, Von Storch H (1998) On the structure and evolution of ENSO-related climate variability in the tropical Pacific: lessons from TOGA. J Geophys Res C 103: $14241-14260$

Ware DM (1995) A century and a half of change in the climate of the NE Pacific. Fish Oceanogr 4(4):267-277

Ware DM, Thomson RE (1991) Link between long-term variability in upwelling and fish production in the northeast Pacific Ocean. Can J Fish Aquat Sci 48:2296-2306

Ware DM, Thomson RE (2000) Interannual to multidecadal timescale climate variations in the northeast Pacific. J Clim 13:3209-3220

Watanabe M, Nitta T (1999) Decadal changes in the atmospheric circulation and associated surface climate variations in the northern hemisphere winter. J Clim 12: 494-510

Weickmann KM, Robinson WA, Penland MC (2000) Stochastic and oscillatory forcing of global atmospheric angular momentum. J Geophys Res D 105:15 543-15557

Wikelski M, Thom C (2000) Marine iguanas shrink to survive El Niño. Nature 403:37

Yáñez E, Barbieri MA, Santillán L (1992) Long-term environmental variability and pelagic fisheries in Talcahuano, Chile. S Afr J Mar Sci 12:175-188

Yasuda I, Sugisaki H, Watanabe Y, Minobe S, Oozeki Y (1999) Interdecadal variations in Japanese sardine and ocean/ climate. Fish Oceanogr 8(1):18-24

Zhang RH, Rothstein LM, Busalacchi AJ (1998a) Origin of upper-ocean warming and El Niño change on decadal scales in the tropical Pacific Ocean. Nature 391:879-883

Zhang X, Sheng J, Shabbar A (1998b) Modes of interannual and interdecadal variability of Pacific SST. J Clim 11: 2556-2569

Zhang Y, Wallace JM, Battisti DS (1997) ENSO-like interdecadal variability. J Clim 10:1004-1020

Submitted: January 11, 2002; Accepted: July 22, 2002

Proofs received from author(s): November 4, 2002 